\title{
Land Capability Index Mapping for Waste Disposal Landuse Option Using Geographic Information System (GIS) in Enugu Area, South Eastern Nigeria
}

\author{
Augustine Onunkwo-Akunne, Samuel Okechukwu Onyekuru, Godwin Ifedilichukwu Nwankwor \\ Department of Geology, Federal University of Technology Owerri, Owerri, Nigeria \\ Email: Onyekuru2001@yahoo.com
}

Received January 2, 2012; revised February 5, 2012; accepted March 14, 2012

\begin{abstract}
The projected 300\% growth rate in the population of Enugu area and its environs by the year 2020 and the expected increase in waste generation necessitated the need to map out areas for waste disposal for future utilization and as a protective strategy for the environment in Enugu area. Land capability index mapping using Geographic Information System (GIS) is one of the appropriate tools required for solving this problem. A total of 12 landuse determinants were selected as thematic data layers, and as basic factors influencing the choice of waste disposal landuse option in the area. The themes (thematic maps) generated from field/laboratory measurements and from literature, include slope, water table, surface and subsurface water conditions, elevation, geology, soil, drainage and geo-structural stability (fault, erosion, landslide and flooding) maps. The maps were scanned, digitized, georeferenced, and polygonized using autocard drawing capabilities to convert them into vector format and later exported to arc view software for analysis. The final processing using overlay model builder yields layers that display areas of preferred waste disposal sites in a map form, which generally shows areas of varying suitability (suitable, moderately (low) suitable and unsuitable). The waste disposal map of Enugu area shows that blocks 1 (Obeagu area) and 3 (Ebe/Nsude areas) represent suitable and unsuitable areas, respectively, while block 2 (Ngwo area) has low suitability for waste disposal.
\end{abstract}

Keywords: Landuse; Thematic Maps; Waste Disposal; Land Capability

\section{Introduction}

The purpose of landuse planning is to make the best, most sensible, practical, safe and efficient use of each parcel of land [1]. Mapping of a land unit for a particular purpose is an aspect of Landuse planning which ensures maximum and safe utilization of land. Enugu area under investigation is presently witnessing high rate of population growth. Accordingly, a projection of the population of Enugu area is pegged at approximately $300 \%$, giving rise to a population figure of about $3,237,298$ people by the year 2020, [2]. Problems of improper waste disposal are always associated with over population in developing countries of the world. This condition usually causes environmental degradation leading to contamination/pollution of the environment. It is therefore, necessary to map out areas of varying capabilities for waste attenuation and containment in the Enugu area for future utilization and as a protective strategy for the environment.

Site evaluation for waste disposal involves the understanding of basic soil components and properties, mechanisms operating in the soil and limitations of the mecha- nisms in terms of pollutant loading rates. It also describes the important criteria used in evaluating land for waste disposal. The factors to be considered in such evaluations include: climate, topography, drainage, soil properties, groundwater, slope, surface water, fault and flood potential [3-11].

The application of Geographic Information System (GIS) in the evaluation of land has widely been acclaimed to facilitate efficient decision making and planning of land use options, [12]. GIS consists of a set of computerized tools and procedures that can be used to effectively store, retrieve, overlay, correlate, manipulate, analyze, query, display (both graphically and numerically) and disseminate land related information, [13].

This approach is applied in the determination of areas with varying degrees of suitability for waste disposal land use option in the Enugu area and environs.

\subsection{Location of Study Area}

The study area is located within Latitudes $6^{\circ} 16^{\prime} \mathrm{N}$ and $6^{\circ} 31 \mathrm{~N}$ and Longitudes $7^{\circ} 20^{\prime} \mathrm{E}$ and $7^{\circ} 41^{\prime} \mathrm{E}$ covering an 
areal extent of about $630 \mathrm{~km}^{2}$ (Figure 1). The area is also located within the rain forest belt of Nigeria and has an average annual rainfall of about $1100 \mathrm{~mm}$ a year, [14].

\subsection{Topography of the Study Area}

The most striking feature within the study area is Enugu-Awgu escarpment. This escarpment is part of the Nsukka-Okigwe Cuesta, which was formed by the resistant sandstones of the lower part of the Ajali Sandstone and the Mamu Formation (Figure 1), [15]. The elevation of the escarpment ranges from $450 \mathrm{~m}$ to about $530 \mathrm{~m}$, while the slopes range between $3 \%$ and $6 \%$ in the dip slope part to between $55 \%$ and $65 \%$ along the scarp face, [16]. Terminating at the foot of the escarpment to the east is the extensive undulating Cross River Plain, underlain by the Enugu Shale.

\subsection{Drainage}

The Enugu-Awgu escarpment forms the most important watershed separating the Cross River system to the east from a network of streams flowing westwards towards the Anambra Basin, [14]. The escarpment is also indented with river valleys, which form the source of streams rising at about the $305 \mathrm{~m}$ elevation and flowing down into deep canyons and v-shaped gullies incised in the weakly bedded and friable sandstones and sands of the Ajali and Mamu Formations, [17]. The rivers and rivulets give rise to dendritic drainage pattern, usually developed in rocks with uniform resistance to weathering and erosion, [18].

\subsection{Geology}

The study area lies in the Anambra Basin of southeastern Nigeria. The basin is of Cretaceous to Tertiary age, $[15,19]$. Five formations that underlie the study area include: Ezeaku Formation (Turonian), Awgu Ndiabo Shale (Santonian), Asata-Nkporo/Enugu Shale (CampanianMaastrichtian), Mamu Formation (middle Maastrichtian) and Ajali Sandstone (late Maastrichtian). The stratigraphic succession is shown in Figure 2 and Table 1. The formations are conformable, although minor discordance may be present, but there is no evidence of any prolonged break in sedimentation, [20].

\subsection{Hydrogeology}

The major water bearing units (aquifers) occur in the Ajali Sandstone that underlie areas to the west of the study area, with a generally deep static water table of about 30 to $40 \mathrm{~m}$ deep, [21]. Aquifers also occur within the Mamu Formation, while some aquitards occur within the Enugu Shale, [18]. The aquitards, are fractured and are tapped by hand dug wells which show high coliform counts, [22]. In the eastern part of Enugu area, the static water table occurs at an average depth of 5 to $9 \mathrm{~m}$ making the area vulnerable to pollution. The generalized depth to water table in the area is shown in Figure 3. It shows that depth to water table decreases from west to east. At the western section, the water table is at an average depth of $60 \mathrm{~m}$ and at the eastern section towards the Cross River plain, the water table is very close to the ground surface averaging about $9 \mathrm{~m}$ deep.

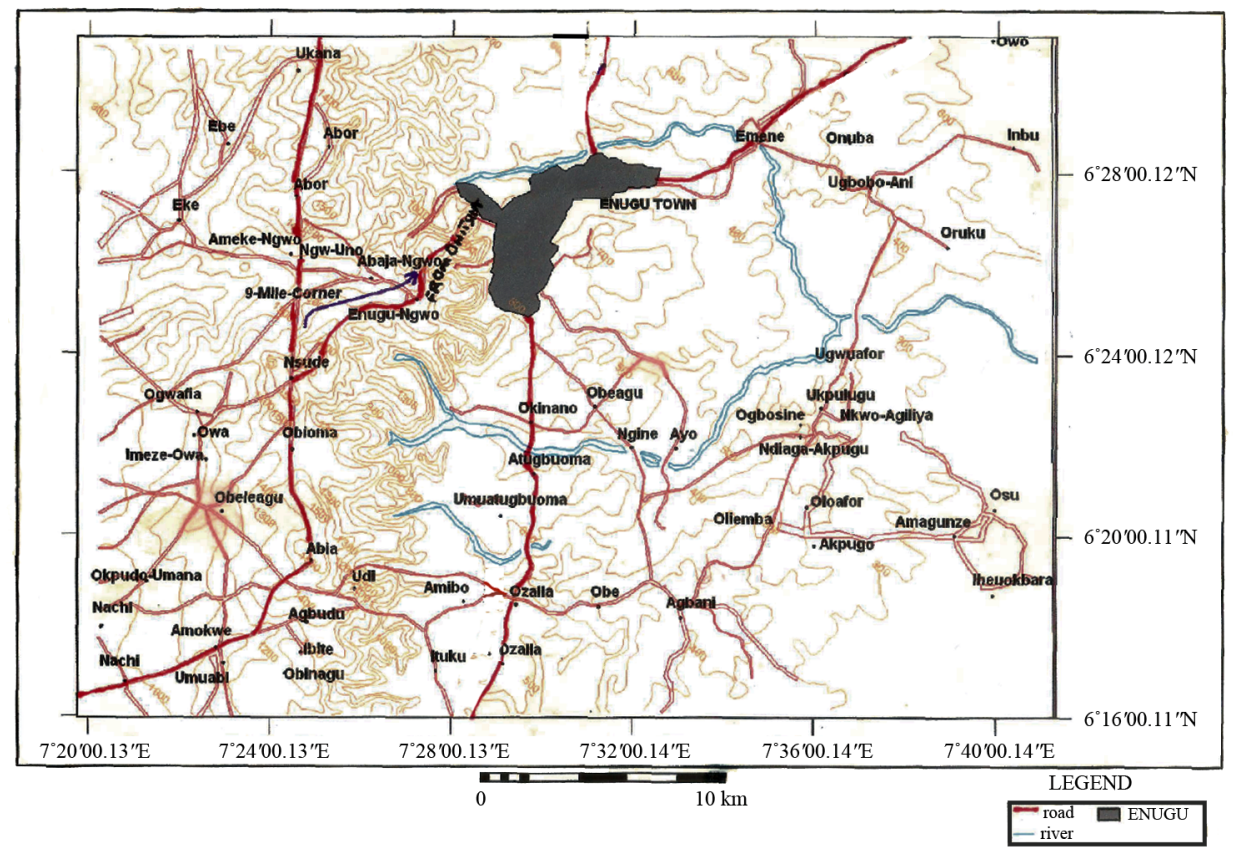

Figure 1. Location map showing Enugu area and environs. 
$7^{\circ} 20^{\prime} \mathrm{E}$

$7^{\circ} 41^{\prime} \mathrm{E}$

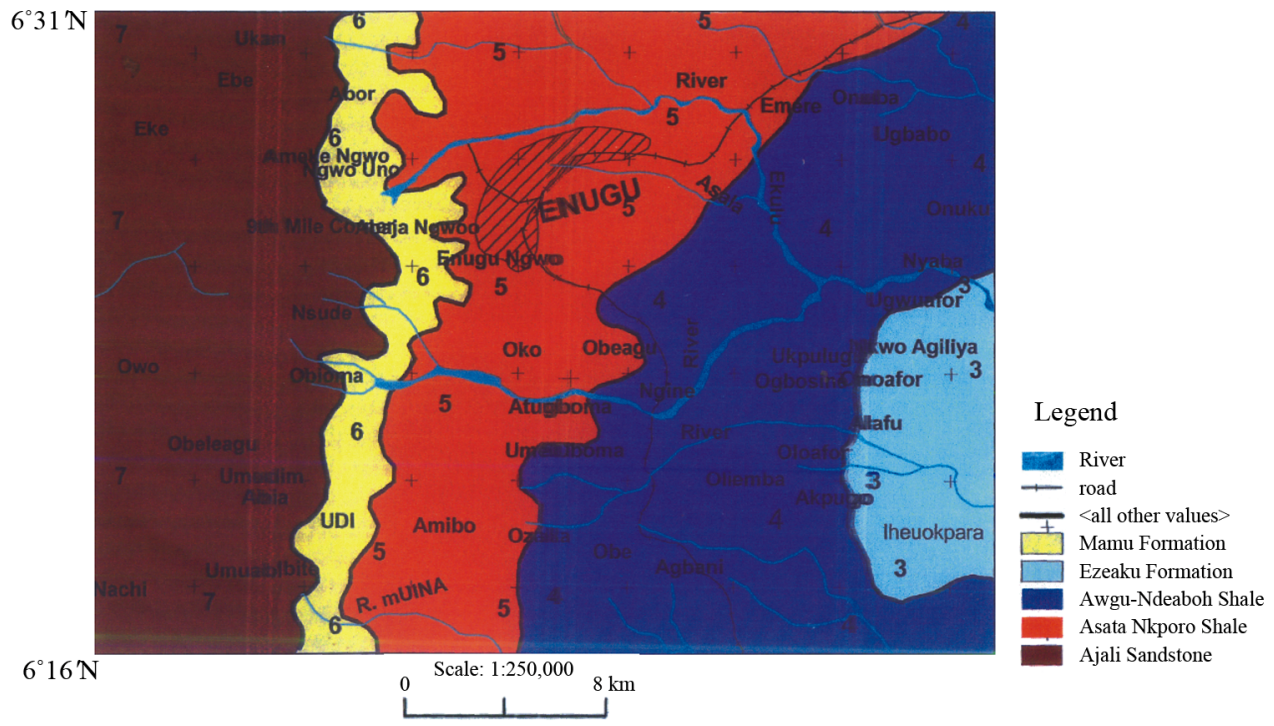

Figure 2. Geological map of Enugu area and environs.

Table 1. Generalized sedimentary sequences in southeastern Nigeria [15].

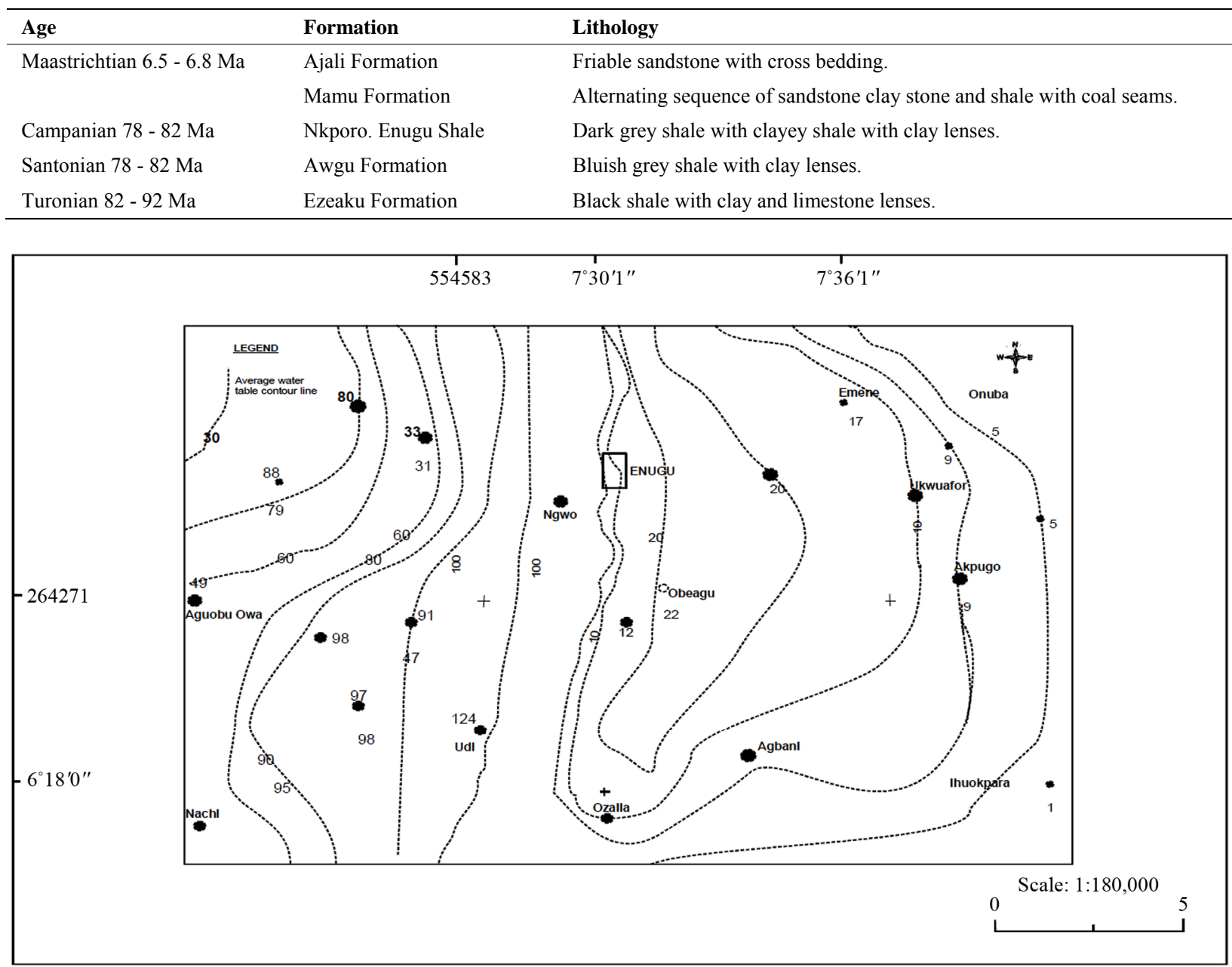

Figure 3. Water table map of the study area. 


\subsection{Soils}

The main soil types in the area are ferralithic and hydromorphic soils, which are derived from the Ajali Sandstones and Enugu Shales underlying the area. The soils derived from Enugu Shale are expansive and have hydraulic conductivity values of about $10^{-5} \mathrm{~m} / \mathrm{s}$, [23]. These soils can be grouped into four classes (based on weathering conditions): Ferralithic Soil (deep, friable and porous), hydromorphic soil (saline soil), lithosoil (thin soils mostly found on hill slopes) and forralithic soils, (Figure 4), [7].

\section{Materials and Methods}

Data required for the analysis of land use options for Enugu Area is divided into primary and secondary data types. The primary data involved information obtained from field and laboratory studies, while secondary data included information obtained from literature and raw data collated from ministries, parastatals, universities and companies.

\subsection{Soil Sampling}

Soil samples were taken randomly from two horizons at Owa, Enugu, Ugwuafor and Agbani. Sampling was carried out by pitting to a fairly considerable depth of 5 and $5.8 \mathrm{~m}$ horizons. Collection was made on fresh samples, while indurated surfaces, humus sections and gravely beds were avoided. The collected soils were preserved in polythene bags and taken to the laboratory for necessary soil tests in accordance with [24] BS standard.

\subsection{Laboratory Studies}

Laboratory investigations carried out on the soils included: particle size analysis, porosity, permeability and Atterberg limit tests.

Samples for particle size distribution analysis were first thoroughly disintegrated by alternate cycles of wetting and drying. The disintegrated material was sieved through $3.35 \mathrm{~mm}, 0.425 \mathrm{~mm}$ to $0.075 \mathrm{~mm}$ sieve meshes after thoroughly shaking the samples with a standard electric sieve shaker. The percentage by weight of soil particles retained on each sieve mesh, were plotted against sieve mesh size to obtain the size distribution pattern of each sediment sample. The particle size distribution of sediments less than $0.075 \mathrm{~mm}$ was determined using the hydrometer method in accordance with [24] BS standard. Only hydromorphic and ferralithic soils were investigated using this method. The hydrometer analysis is based on Stroke law and indicates the percentage of clay fraction present in a sample of soil.

The porosity and permeability of the soils were also determined as one of the necessary parameters used in delineating potential of an area for waste disposal landuse option. The tests were carried out on the hydromorphic, ferralithic and forralithic soils using falling head method.

\section{Results and Data Analysis}

The results of particle size distribution of 3 samples representing the different soil types in Enugu area is presented in Tables 2-4 and Figures 5-7. The results
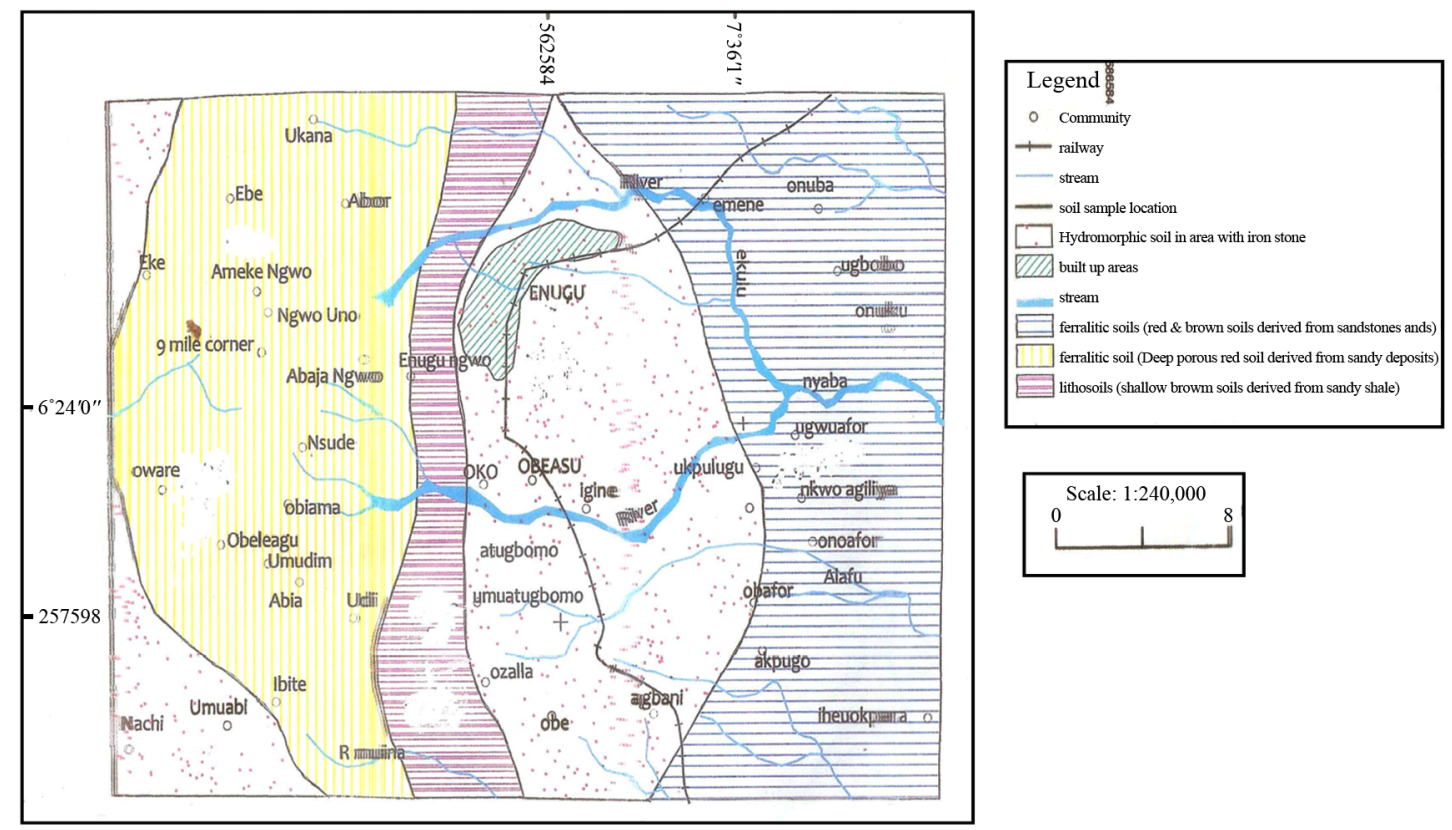

Figure 4. Soil map of Enugu area. 
Table 2. Grain size data for ferralithic soil.

\begin{tabular}{|c|c|c|c|c|}
\hline Sieve Size (mm) & Mass retained & Cumulative mass retained (g) & \% Cum-mass retained & \% Passing \\
\hline 5.56 & 0 & 0 & 0 & 100 \\
\hline 3.35 & 0.2 & 0.2 & 0.04 & 99.96 \\
\hline 2.0 & 2.1 & 2.3 & 0.46 & 99.54 \\
\hline 1.18 & 33.1 & 35.4 & 7.08 & 92.92 \\
\hline 0.6 & 60.8 & 96.2 & 19.24 & 80.76 \\
\hline 0.425 & 98.6 & 194.8 & 38.96 & 61.04 \\
\hline 0.5 & 97.8 & 292.6 & 58.52 & 41.48 \\
\hline 0.212 & 84.0 & 377.6 & 75.52 & 14.48 \\
\hline 0.15 & 85.6 & 463.2 & 92.64 & 7.36 \\
\hline 0.075 & 32.8 & 496.0 & 99.20 & 0.8 \\
\hline Received & 3.4 & 499.4 & 99.98 & 0.02 \\
\hline
\end{tabular}

Table 3. Grain size data for forralithic soil.

\begin{tabular}{ccccc}
\hline Sieve Size (mm) & Mass retained & Cumulative mass retained & \% Cum-mass retained & \% Passing \\
\hline 3.35 & 0 & 0 & 0 & 100 \\
2.0 & 0.2 & 0.2 & 0.04 & 99.56 \\
1.18 & 2.8 & 3.0 & 0.6 & 99.4 \\
0.6 & 8.7 & 11.7 & 2.34 & 97.66 \\
0.425 & 19.1 & 30.8 & 6.16 & 93.84 \\
0.3 & 21.7 & 52.5 & 10.5 & 89.5 \\
0.212 & 56.0 & 108.5 & 21.7 & 78.3 \\
0.15 & 153.2 & 261.7 & 52.34 & 47.3 \\
0.075 & 191.0 & 452.7 & 90.54 & 9.46 \\
Received & 47.0 & 495.7 & 99.94 & 0.06 \\
\hline
\end{tabular}

Table 4. Grain size data for hydromorphic soil.

\begin{tabular}{ccccc}
\hline Sieve Size (mm) & Mass retained(g) & Cumulative mass retained (g) & \% Cum-mass retained & \% Passing \\
\hline 28.0 & 0 & 10 & 0 & 100 \\
19.0 & 18.4 & 18.4 & 374 & 96.26 \\
14.0 & 6.2 & 24.6 & 10.55 & 95.00 \\
10.0 & 27.3 & 51.9 & 26.75 & 89.45 \\
5.6 & 76.6 & 131.5 & 43.26 & 73.25 \\
3.35 & 81.3 & 212.8 & 57.65 & 56.12 \\
2.0 & 70.6 & 283.4 & 67.34 & 42.35 \\
1.18 & 57.3 & 340.9 & 75.34 & 30.66 \\
0.6 & 30.5 & 371.4 & 78.28 & 24.46 \\
0.425 & 13.4 & 384.8 & 80.41 & 21.72 \\
0.3 & 10.5 & 395.6 & 81.69 & 19.59 \\
0.212 & 6.3 & 401.6 & 87.04 & 18.31 \\
0.15 & 26.3 & 427.9 & 94.43 & 12.96 \\
0.075 & 36.3 & 464.2 & 98.03 & 5.57 \\
Received & 17.7 & 481.9 & & 1.97 \\
\hline
\end{tabular}




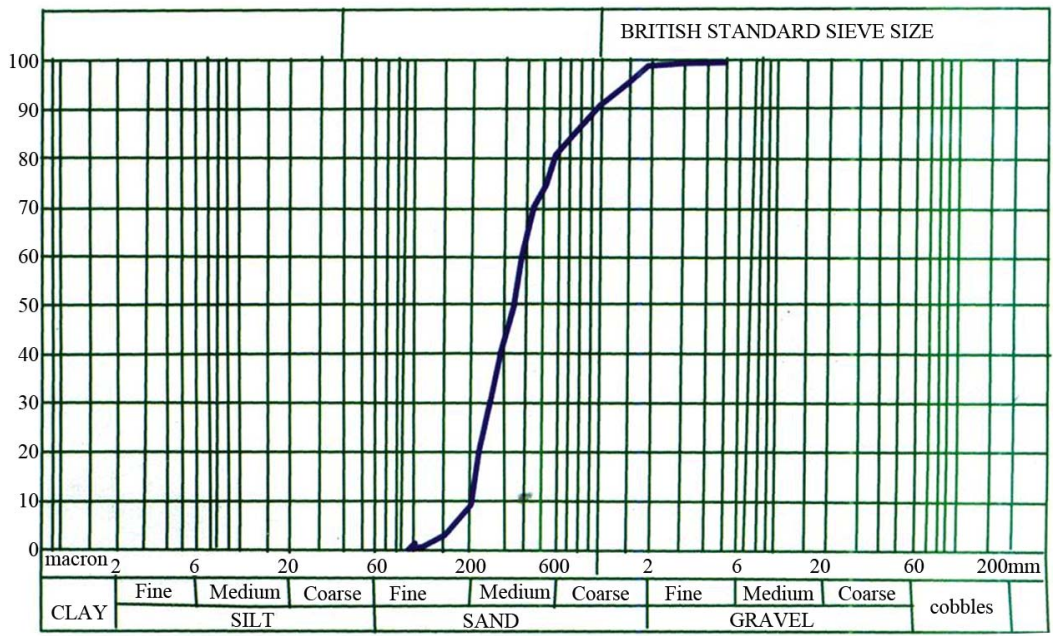

Figure 5. Grain size distribution of the forralithic soil (Owa).

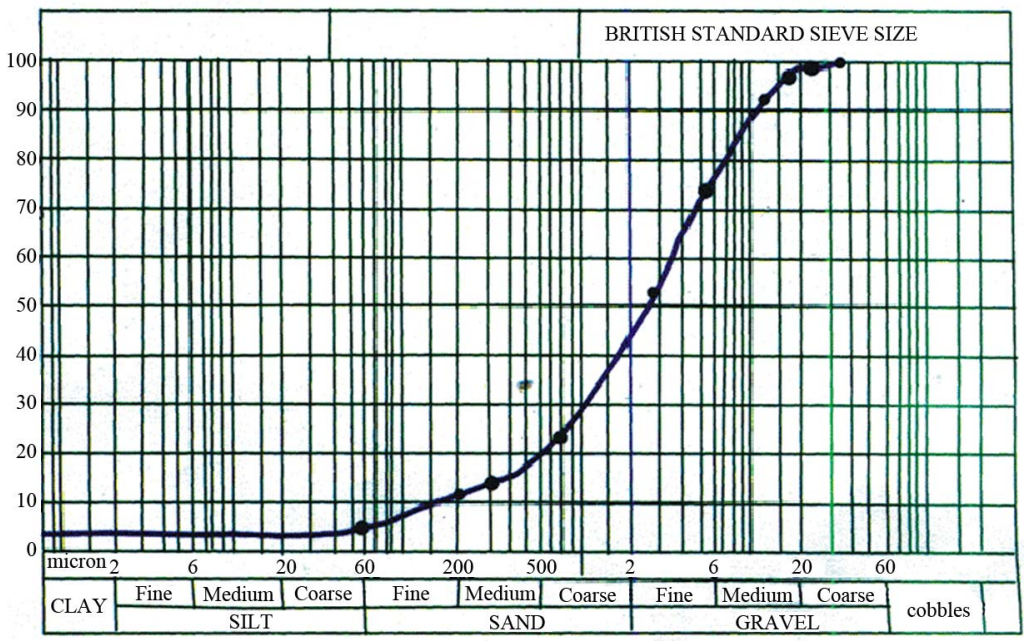

Figure 6. Grain size distribution of the ferralithic soil (Ugwuafor).

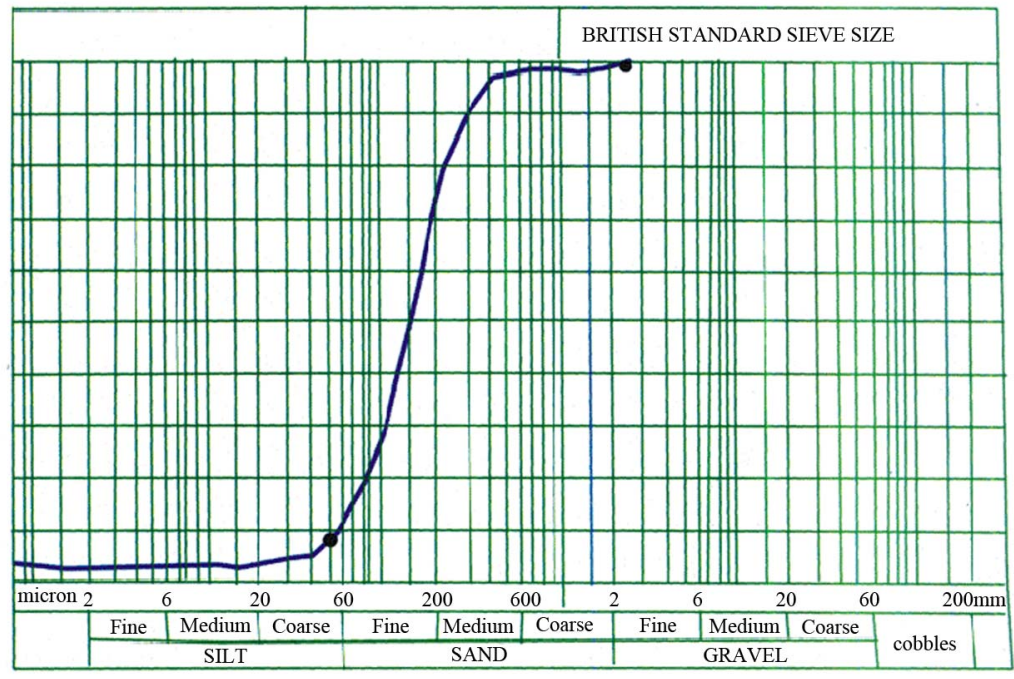

Figure 7. Grain size distribution of the hydromorphic soil (Enugu). 
show that forralithic soils can be grouped as sandy clay soils while hydromorphic and ferralithic soils are silty clay soils.

The plots of hydrometer analysis for the two soil types (ferralithic and hydromorphic soils) are shown in Figures 8(a) and (b), which show that the clay fraction of the hydromorphic soil is $13 \%$ and that of ferralithic soil is $13.5 \%$ in the analyzed samples.

The result of the falling head test for some of soil types in the study area is shown in Table 5. The Forralithic and hydromorphic soils have higher porosity and permeability which corroborates the work of [25].

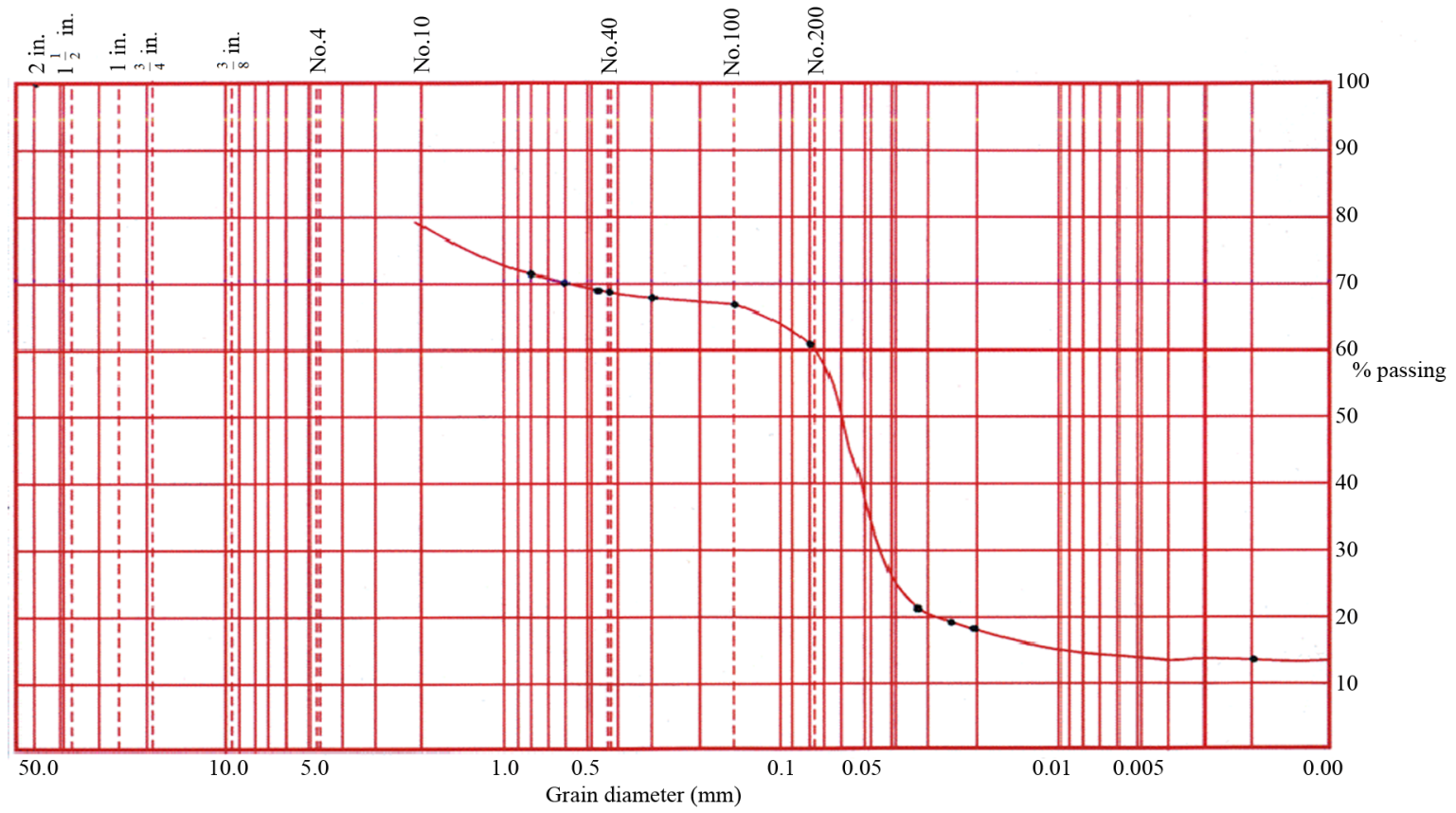

(a)

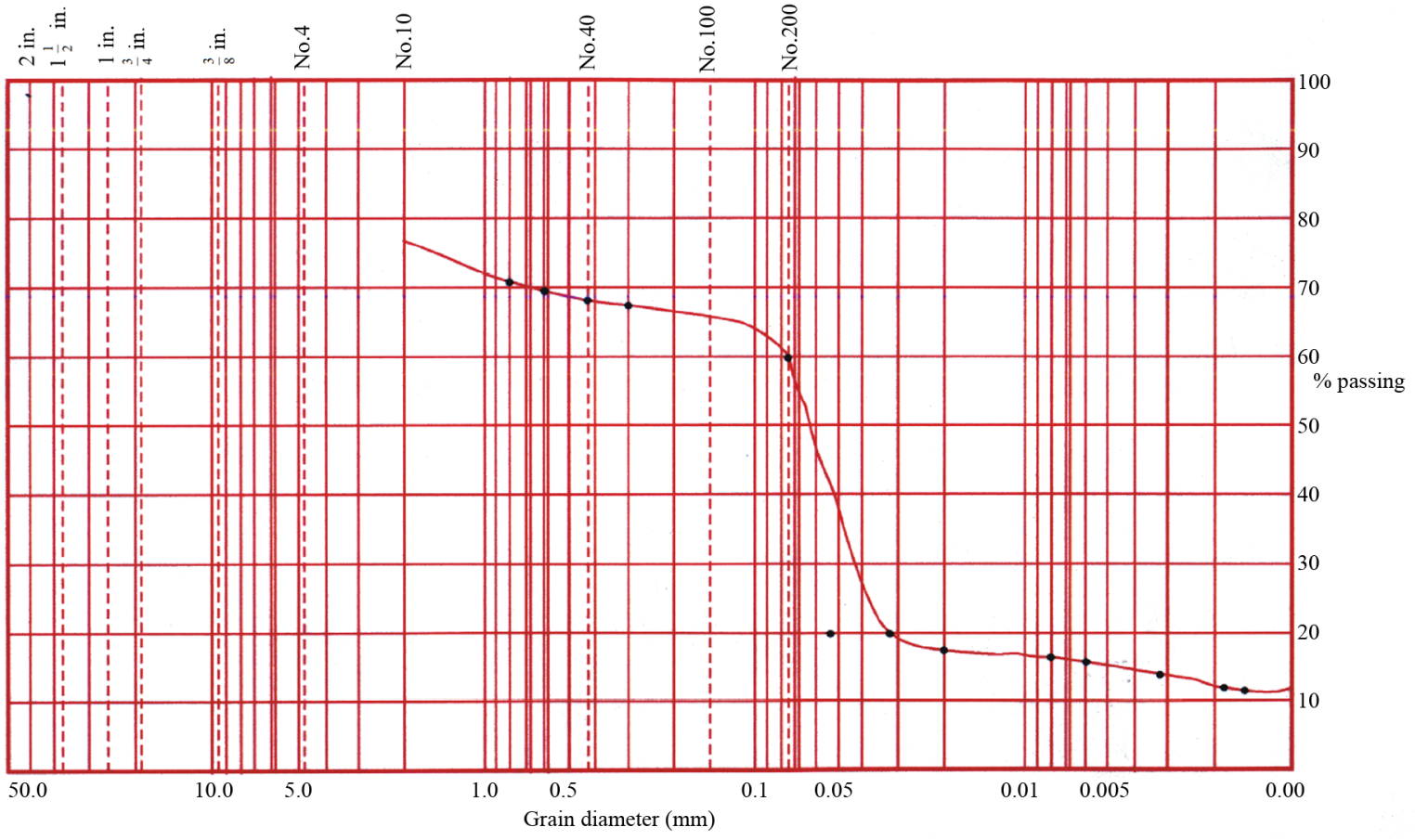

(b)

Figure 8. (a) Plot of grain size analysis result using hydrometer for ferralithic soil; (b) Plot of grain size analysis result using hydrometer for hydromorphic soil. 
Table 5. Permeability and porosity of soils in Enugu area.

\begin{tabular}{ccc}
\hline Soil Type & Permeability (cm/s) & Porosity (\%) \\
\hline Hydromorphic Soil & $1.97 \times 10^{-2}$ & 31 \\
Ferralithic Soil & $1.89 \times 10^{-2}$ & 30 \\
Forralithic Soil & $1.92 \times 10^{-2}$ & 31 \\
\hline
\end{tabular}

Similarly, the following physical properties of lithosoils that also underlie part of the study area have also been defined, [16]: shear strength $=88.36 \mathrm{~N} / \mathrm{m}^{2}$, porosity $=30 \%$ and permeability is $1.70 \mathrm{~cm} / \mathrm{s}$, soil group is silty sand.

\subsection{Engineering Classification of Soils}

The Unified Soil Classification System (USCS; Table 6) used particle size distribution and Atterberg Limit Data (Tables 7-9) to describe two main soil groups in the study area: coarse and fine grained soils. The plasticity chart (Figure 9) also used grain size distribution and Atterberg limit data (Tables 7-9) to characterize three classes of soils in the study area (Forralithic Soil, Hydromorphic Soil and Ferralithic Soil): Forralithic soils, plotted on CL-ML field (Figure 9) representing silty clay and poorly graded soils. Hydromorphic soil plotted on SP-CL field which is silty clay and poorly sorted soils. Ferralithic soil plotted on SW-CL field which is silty clay and well sorted soils.

\subsection{Thematic Maps}

Twelve thematic maps generated from the various field and laboratory operations and from literature were employed as basic landuse determinants in the study area. The maps are the themes that form data layers for Geographic Information System (GIS) operation. The thematic maps were first scanned at $150 \mathrm{dpi}$ (dot per inch) resolutions, digitized, polygonized and georeferenced

Table 6. Unified soil classification system.

\begin{tabular}{|c|c|c|c|c|c|}
\hline $\begin{array}{l}\text { Major } \\
\text { Divisions }\end{array}$ & Subdivisions & $\begin{array}{l}\text { USCS } \\
\text { Symbol }\end{array}$ & Typical Names & $\begin{array}{l}\text { Laboratory } \\
\text { Classification } \\
\text { Criteria }\end{array}$ & Remarks \\
\hline \multirow{8}{*}{$\begin{array}{l}\text { Coarse Grained } \\
\text { Soil (More than } \\
50 \% \text { Retained } \\
\text { on No. } 200 \\
\text { Sieve }\end{array}$} & \multirow{4}{*}{$\begin{array}{l}\text { Gravels (More than } \\
50 \% \text { Retained on } \\
\text { No. } 4 \text { Sieve }\end{array}$} & GW & $\begin{array}{l}\text { Well Graded Gravels, or gravel- } \\
\text { sand mixtures with little or no fines }\end{array}$ & Less than $5 \%$ fines & $\mathrm{C} \geq-4$ and $1 \leq \mathrm{C} \leq 3$ \\
\hline & & GP & $\begin{array}{l}\text { Poorly Graded Gravels, or } \\
\text { gravely sands, little or no fines }\end{array}$ & Less than $5 \%$ fines & $\begin{array}{l}\text { Does not meet } \mathrm{C} \text { and or } \\
\mathrm{C} \text { criteria listed above }\end{array}$ \\
\hline & & GM & Silty Gravels and sand mixtures & More than $12 \%$ fines & $\begin{array}{l}\text { Minus No. } 40 \text { Soils plot } \\
\text { above A Line }\end{array}$ \\
\hline & & $\mathrm{GC}$ & $\begin{array}{l}\text { Silty Gravels, Gravels and clay } \\
\text { Mixtures }\end{array}$ & More than $12 \%$ fines & $\begin{array}{l}\text { Minus No. } 40 \text { Soils plot } \\
\text { above A Line }\end{array}$ \\
\hline & \multirow{4}{*}{$\begin{array}{l}\text { Sands }(50 \% \text { or } \\
\text { more of coarse } \\
\text { fraction passing } \\
\text { No. } 4 \text { Sieve) }\end{array}$} & SW & $\begin{array}{l}\text { Well graded Sands or Gravelly } \\
\text { Sands, little or no fines }\end{array}$ & Less than $5 \%$ fines & $\mathrm{C} \geq-6$ and $1 \leq \mathrm{C} \leq 3$ \\
\hline & & SP & $\begin{array}{l}\text { Poorly Graded Sands or Gravelly } \\
\text { Sands little or no fines }\end{array}$ & Less than $5 \%$ fines & $\begin{array}{l}\text { Does not meet } \mathrm{C} \text { and or } \\
\mathrm{C} \text { criteria listed above }\end{array}$ \\
\hline & & SM & Silty Sands, Sand Silt Mixtures & More than $12 \%$ fines & $\begin{array}{l}\text { Minus No. } 40 \text { Soils plot } \\
\text { above A Line }\end{array}$ \\
\hline & & $\mathrm{SC}$ & $\begin{array}{l}\text { Clayey Sands, Clay-Sand } \\
\text { Mixtures }\end{array}$ & More than $12 \%$ fines & $\begin{array}{l}\text { Minus No. } 40 \text { Soils plot } \\
\text { above A Line }\end{array}$ \\
\hline \multirow{6}{*}{$\begin{array}{l}\text { Fine Grained } \\
\text { Soils }(50 \% \text { or } \\
\text { more passes } \\
\text { No. } 200 \text { Sieve }\end{array}$} & \multirow{3}{*}{$\begin{array}{l}\text { Silts and Clays } \\
\text { (Liquid Limit < } \\
50 \% \text { ) }\end{array}$} & ML & $\begin{array}{l}\text { Inorganic silts, rock, flour, silts } \\
\text { of low plasticity }\end{array}$ & Inorganic soil & $\begin{array}{l}\mathrm{PL}<4 \text { or Plots below } \mathrm{A} \\
\text { Line }\end{array}$ \\
\hline & & $\mathrm{CL}$ & $\begin{array}{l}\text { Inorganic Clays of low plasticity } \\
\text { (Gravel Clays, Sandy Clays, etc. }\end{array}$ & Inorganic soil & $\begin{array}{l}\text { PL }>7 \text { or Plots above A } \\
\text { Line }\end{array}$ \\
\hline & & $\mathrm{OL}$ & $\begin{array}{l}\text { Organic Silts, Organic Clays } \\
\text { of low plasticity }\end{array}$ & Organic soil & $\begin{array}{l}\text { LL (Oven-Dried) LL } \\
\text { (Not Oven Dried) } 0.75\end{array}$ \\
\hline & \multirow{3}{*}{$\begin{array}{l}\text { Silts and Clays } \\
\text { (Liquid Limit } 50 \% \\
\text { or more) }\end{array}$} & $\mathrm{MH}$ & $\begin{array}{l}\text { Inorganic silts, micaceous silts, } \\
\text { silts of high plasticity }\end{array}$ & Inorganic soil & Plots below A Line \\
\hline & & $\mathrm{CH}$ & $\begin{array}{l}\text { Inorganic highly plastic Clays, } \\
\text { fat clays, silty clays, etc. }\end{array}$ & Inorganic soil & Plots on or above A line \\
\hline & & $\mathrm{OH}$ & $\begin{array}{l}\text { Organic Silts and Organic Clays } \\
\text { of high plasticity }\end{array}$ & Organic soil & $\begin{array}{l}\text { LL (Oven-Dried) LL } \\
\text { (Not Oven Dried) } 0.75\end{array}$ \\
\hline Peat & Highly Organic & PT & $\begin{array}{l}\text { Peat and other highly } \\
\text { organic soils }\end{array}$ & $\begin{array}{l}\text { Primary organic } \\
\text { matter, dark in colour }\end{array}$ & \\
\hline
\end{tabular}


Table 7. Soil parameters determined for forralithic soils.

\begin{tabular}{ccc}
\hline US Sieve & \% passing & Atterberg limits \\
\hline N04 (3.35) & 99.96 & \\
N010 (2.0) & 99.54 & LL $=26.06 \%$ \\
N040 (0.425) & 01.04 & PL $=19.75 \%$ \\
N0100 (0.15) & 7.36 & PI $=6.31 \%$ \\
N0200 (0.075) & 0.8 & \\
\hline
\end{tabular}

Table 8. Soil parameters determined for hydromorphic soils.

\begin{tabular}{ccc}
\hline US Sieve & \% passing & Atterberg limits \\
\hline N04 (3.35) & 100 & \\
N010 (2.0) & 99.6 & LL $=43.3 \%$ \\
N040 (0.425) & 93.8 & PL $=16.89 \%$ \\
N0100 (0.15) & 47.3 & PI $=26.46 \%$ \\
N0200 (0.075) & 9.5 & \\
\hline
\end{tabular}

Table 9. Soil parameters determined for ferralithic soils.

\begin{tabular}{ccc}
\hline US Sieve & \% passing & Atterberg limits \\
\hline N04 (3.35) & 56.12 & \\
N010 (2.0) & 42.35 & LL $=39.84 \%$ \\
N040 (0.425) & 21.96 & PL $=14.70 \%$ \\
N0100 (0.15) & 12.96 & PI $=25.14 \%$ \\
N0200 (0.075) & 5.57 & \\
\hline
\end{tabular}

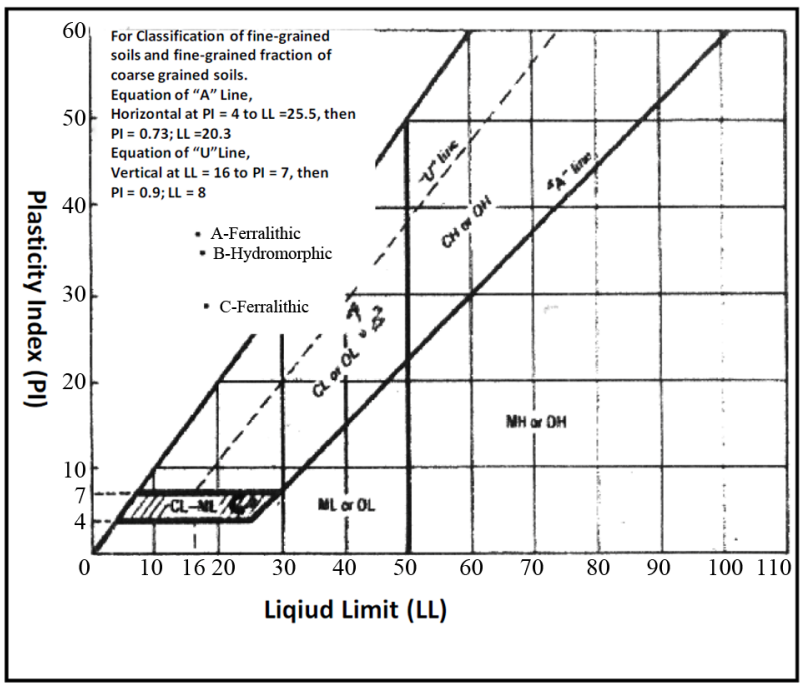

Figure 9. Unified soil classification system-plasticity chart.

with 4 control points of $6^{\circ} 16^{\prime} \mathrm{N}$ and $6^{\circ} 31 \mathrm{~N}$ (Latitude) and $7^{\circ} 20^{\prime} \mathrm{E}$ and $7^{\circ} 41^{\prime} \mathrm{E}$ (Longitude). The digitized thematic maps include: elevation map, slope map, soil depth map, drainage map, soil class map, surface water map, depth to water table map, erosion map, escarpment map, fault map, flood/landslide map and geologic map of the study area (Figures 10-21). These data base (thematic maps) were modified using excel statistical software and geographic calculator and arranged as distinct layers. Data analysis also involved conversion of the collected elevation values and coordinates to national grid. With the aid of the topographic map of Enugu area and the Geographic Positioning System (GPS), the 3D Digital Terrain Model (DTM) of the study area was developed in Arc view by the extrapolation of elevation values at 100 $\mathrm{m}$ range (Figure 22). The DTM of the area revealed detailed picture of the drainage pattern that aided selection of waste disposal sites free from environment of internal drainage, [3].

\subsection{Organization of Geographic Input Data and the Establishment of GIS Data Layers}

The thematic data layers used in this work are relevant for waste disposal land use option (Table 10). The scale values of the tables are the capability ratings assigned to each environmental factor based on a scale of $0-2$, to make up three classes of landuse representing zones of unsuitable (0), low suitability (1) and suitable (2). A zero (0) capability value renders the land of any area very unsuitable as the capability values of other landuse factors within the same polygon remains zero irrespective of their high suitability values, [26].

\subsection{Overlay Process}

The input themes (thematic layers) were overlaid using computer iterative technique starting from theme I to 12 (Figure 23). This operation was done by the selection of a model builder from the operational table (Table 10) using the Arc view software. Individual themes are added to one another using the matrix operation of the form:

$$
\left(\begin{array}{c}
T_{1} \\
T_{12}
\end{array}\right) \times \text { Scale Value: }
$$

This operation produced a waste disposal land use map (Figure 24). The waste disposal map shows that areas 1 (Obeagu area) and 3 (Ebe/Nsude areas) represent suitable and unsuitable areas, respectively, while 2 (Ngwo area) has low suitability for waste disposal.

\section{Discussion}

The result of the overlay operations produced the preferred areas for waste disposal land use option. The map shows various areas of capabilities for waste disposal designated as areas 1, 2 and 3 representing suitable, unsuitable and low suitability, respectively. The study shows that area 1 (Obeagu area) occupies $60 \%$ of the land area that is suitable for waste disposal. This means that the greater percentage of Enugu area is suitable for 


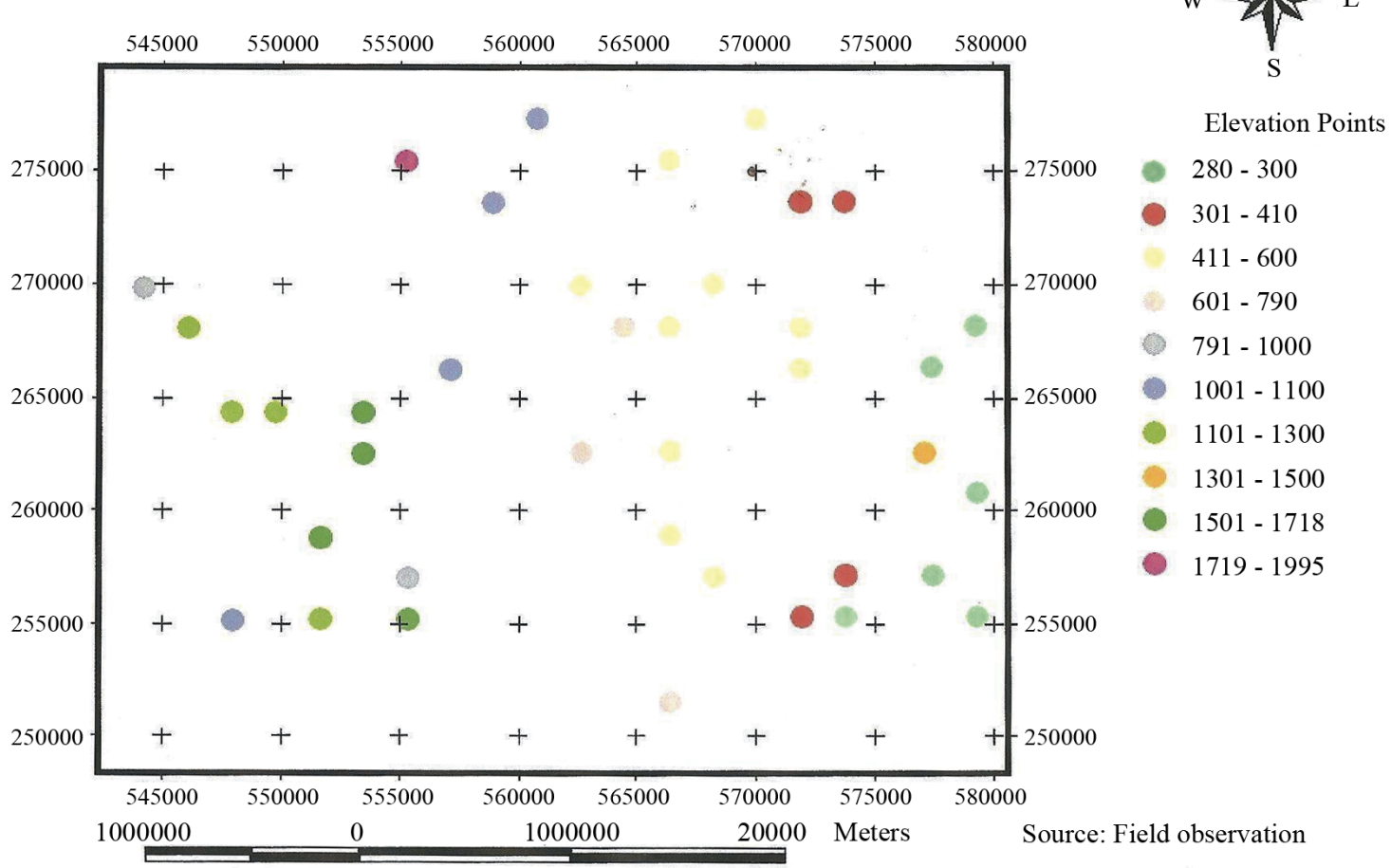

Figure 10. Digitized elevation map of Enugu area.

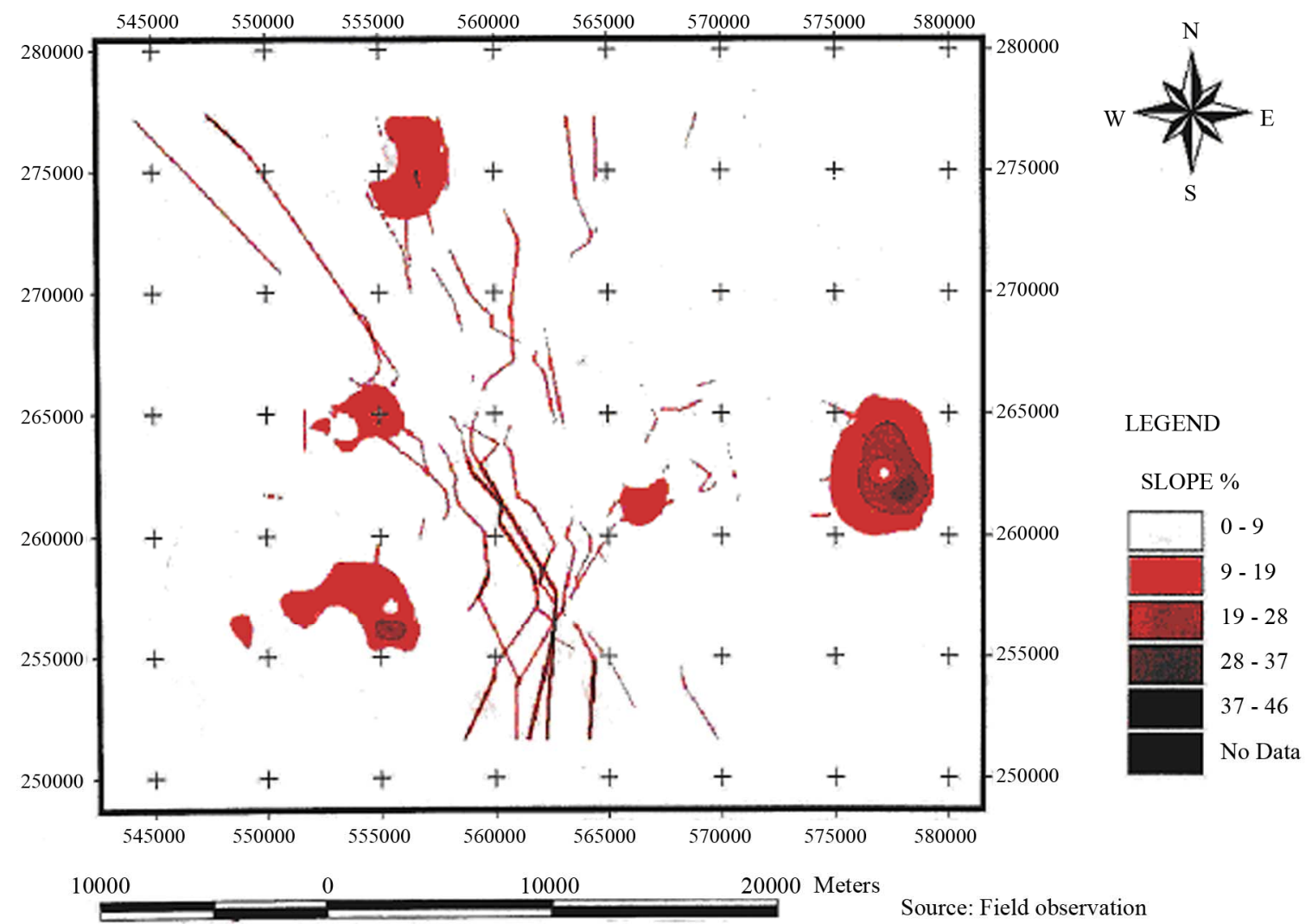

Figure 11. Digitized slope map of the study area. 


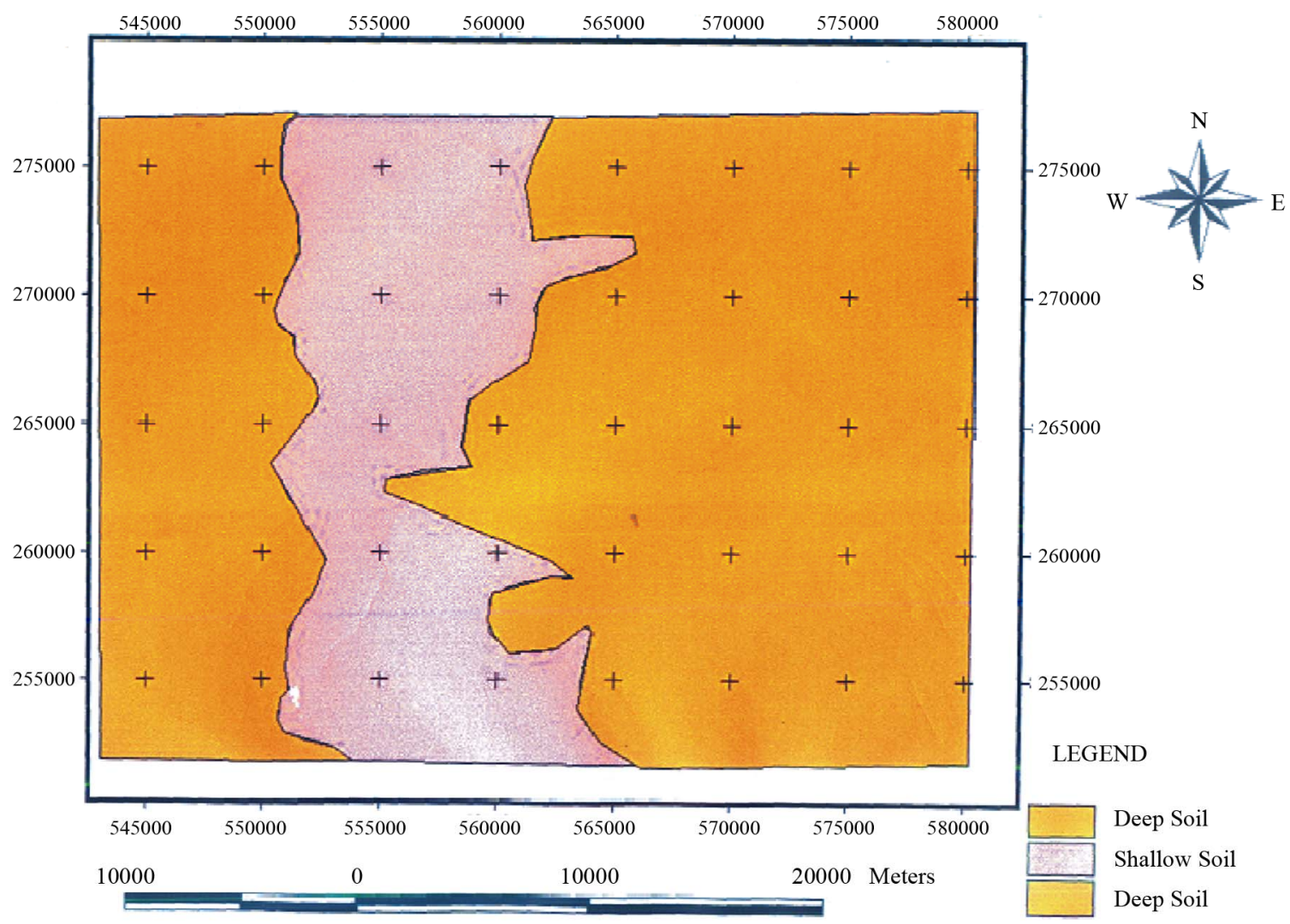

Figure 12. Soil-depth maps of the study area.

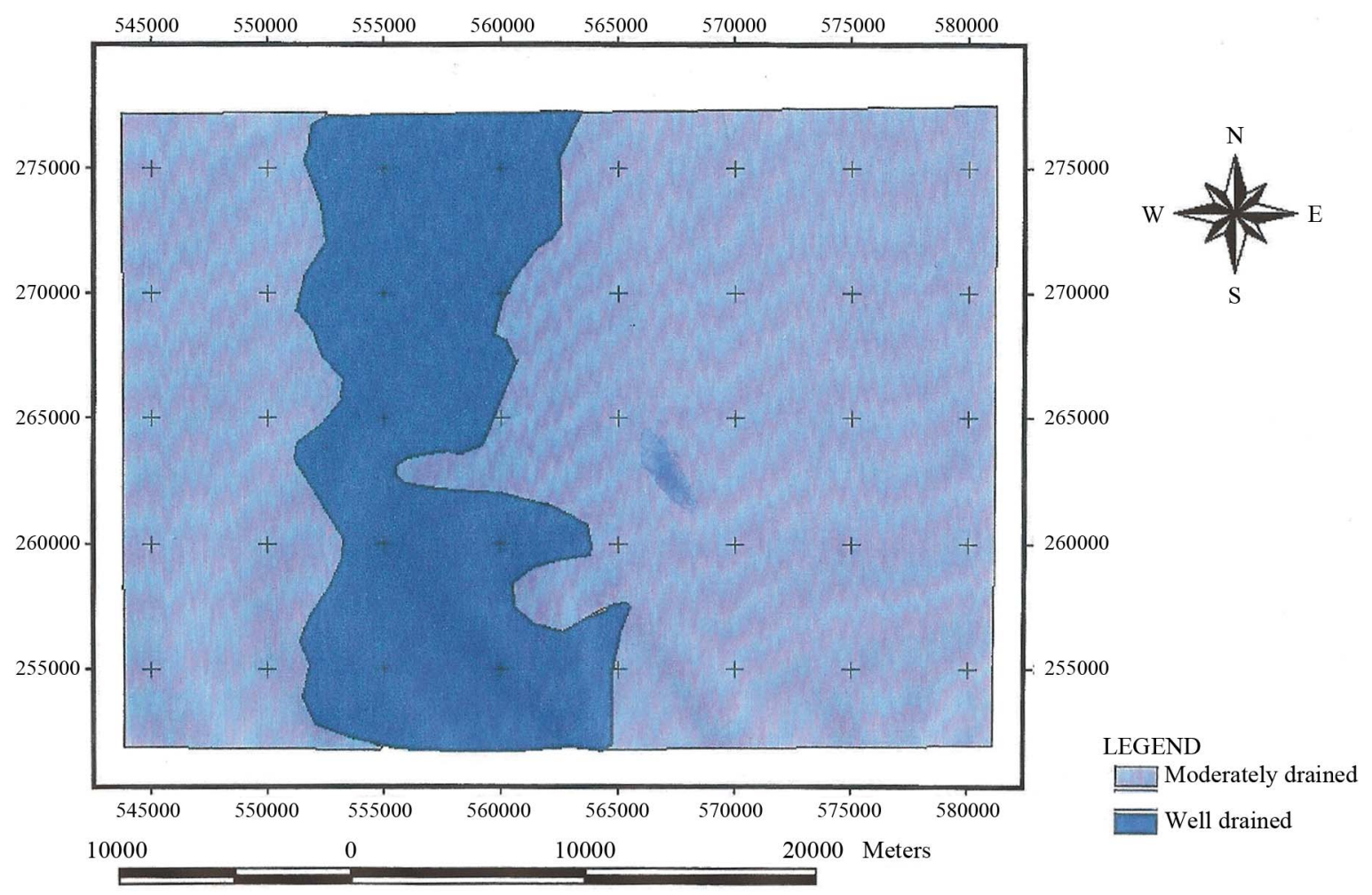

Figure 13. Digitized and polygonized soil drainage maps. 


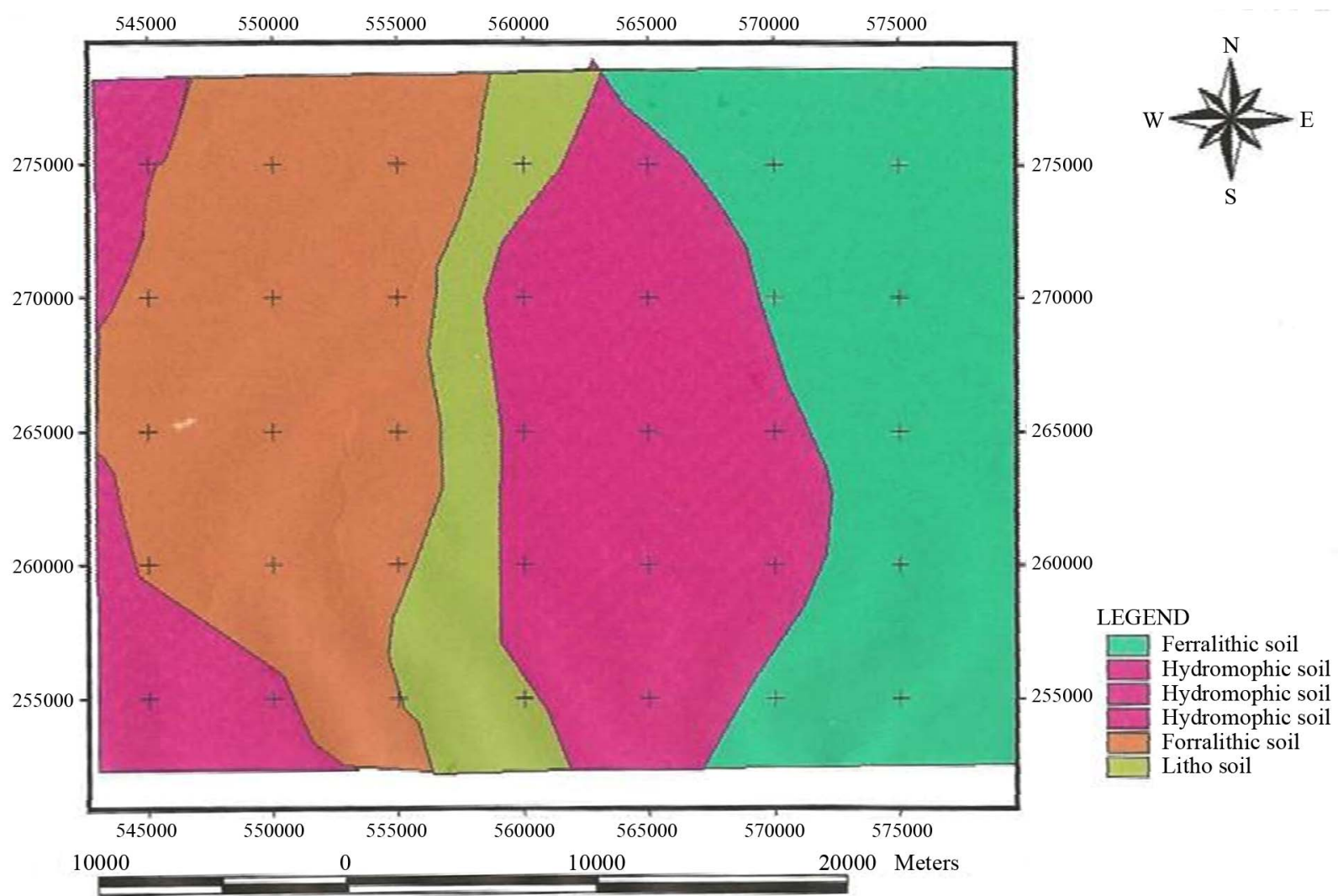

Figure 14. Digitized and polygonized soil class map.

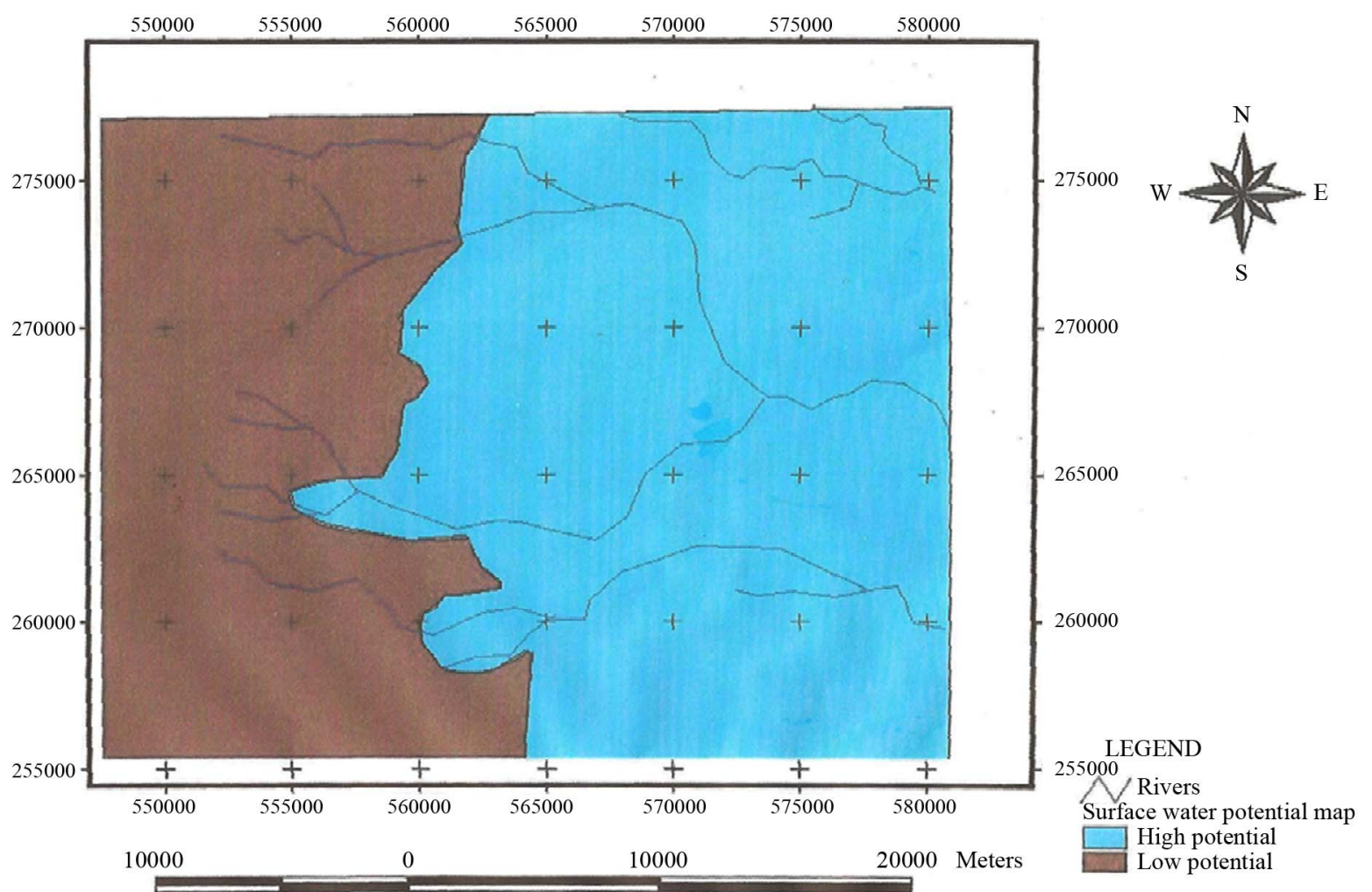

Figure 15. Digitized and polygonized surface water map. 


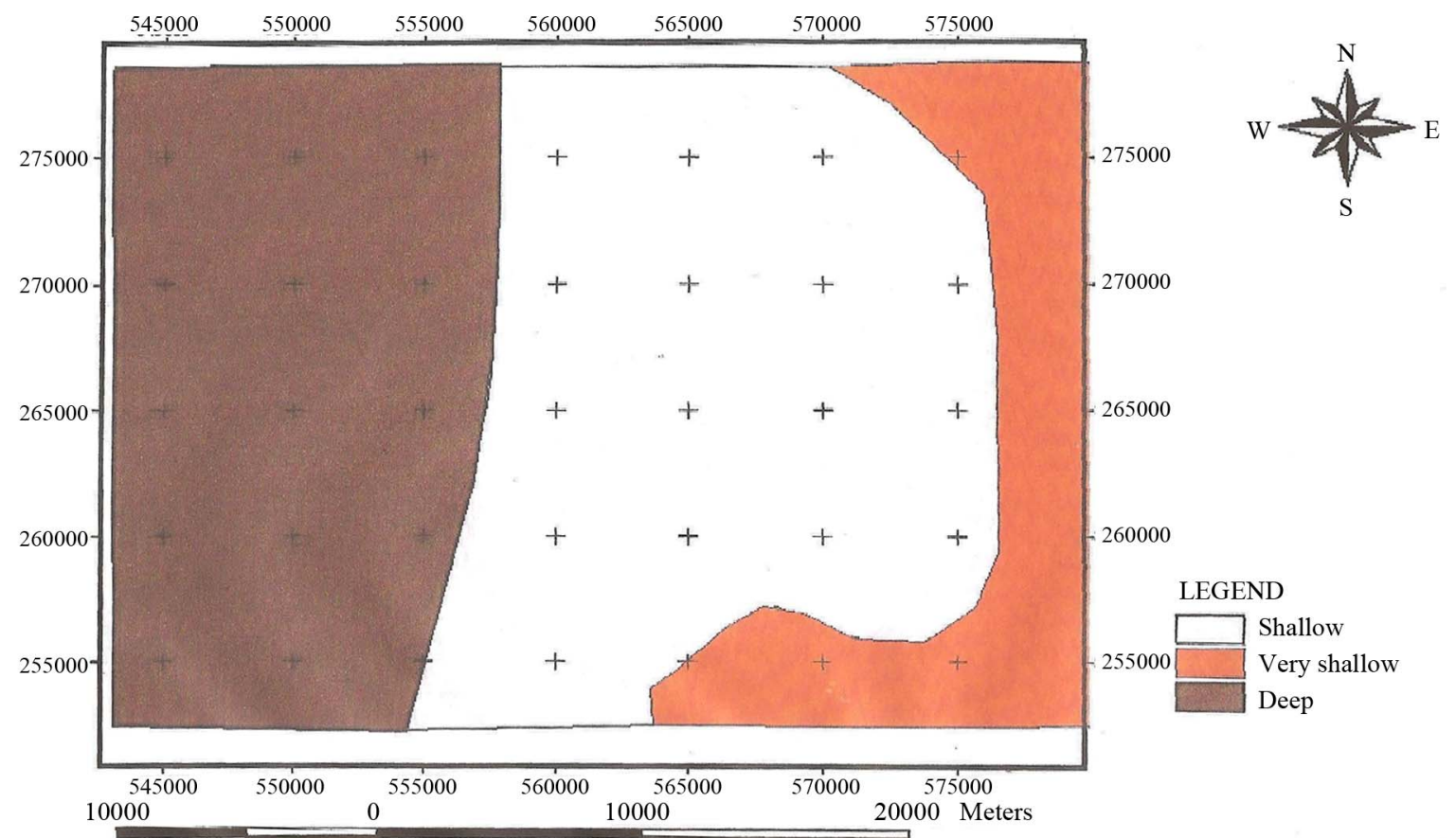

Figure 16. Digitized and polygonized water table map.

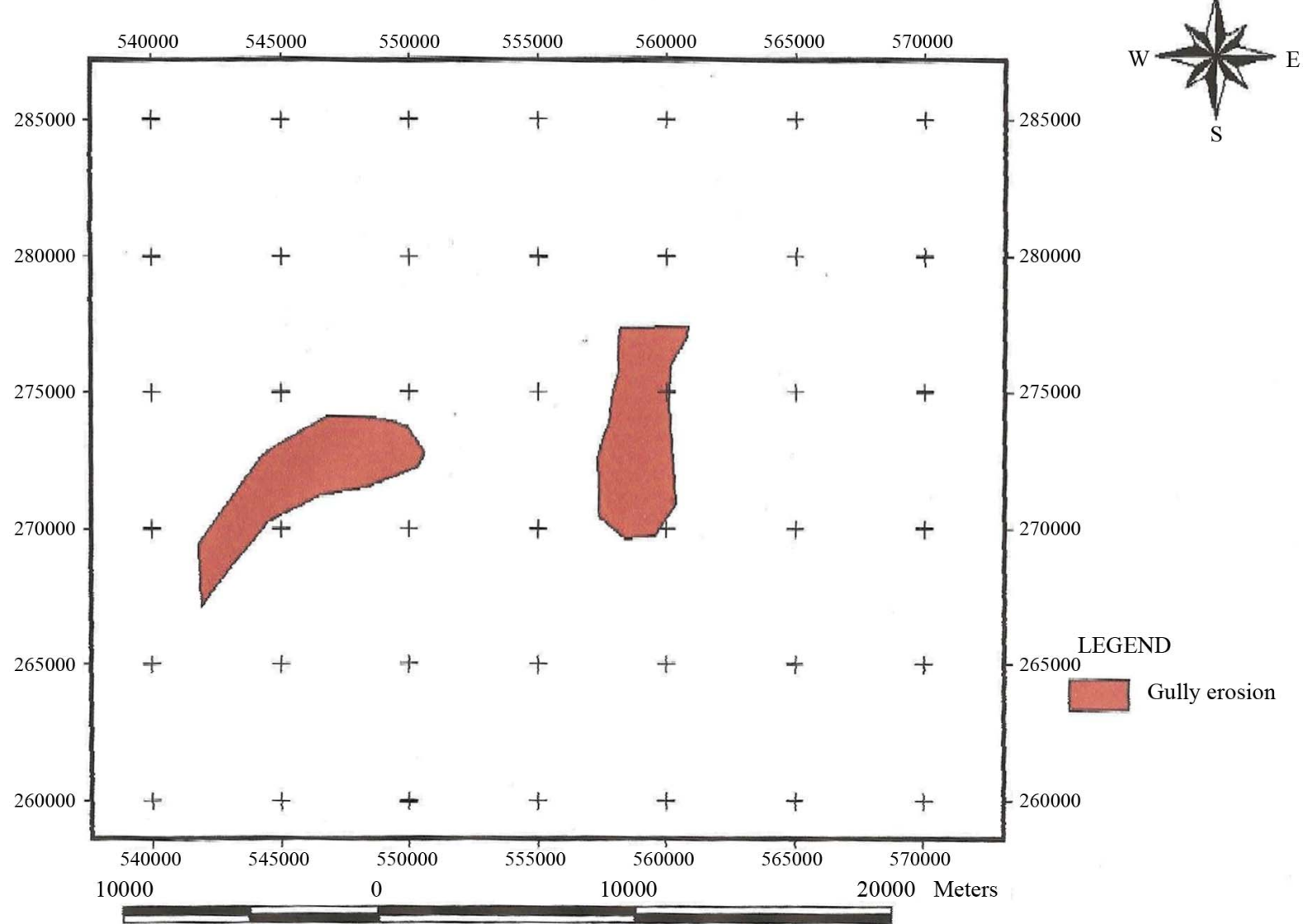

Figure 17. Digitized and buffered gully erosion map. 


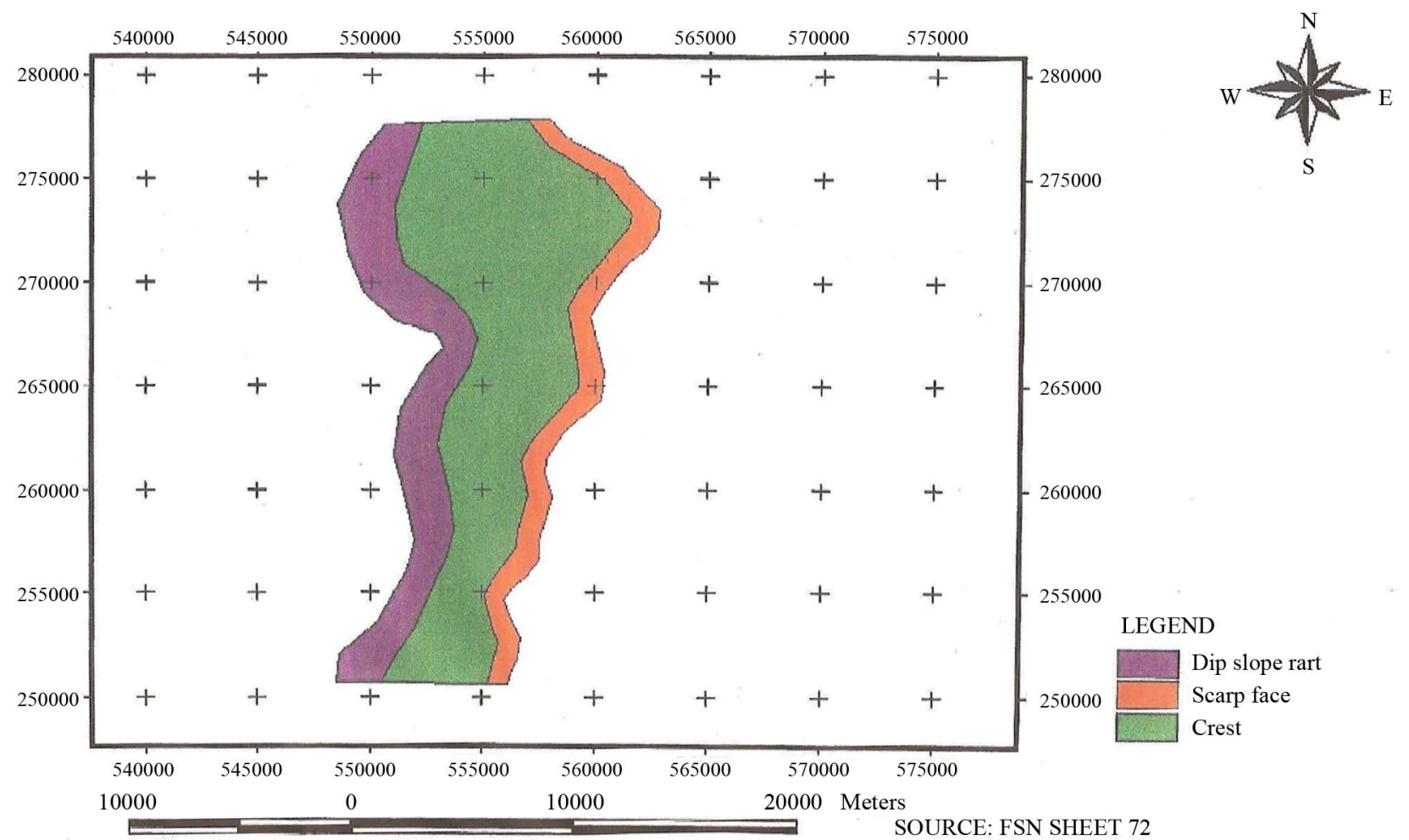

Figure 18. Digitized and polygonized escarpment map.

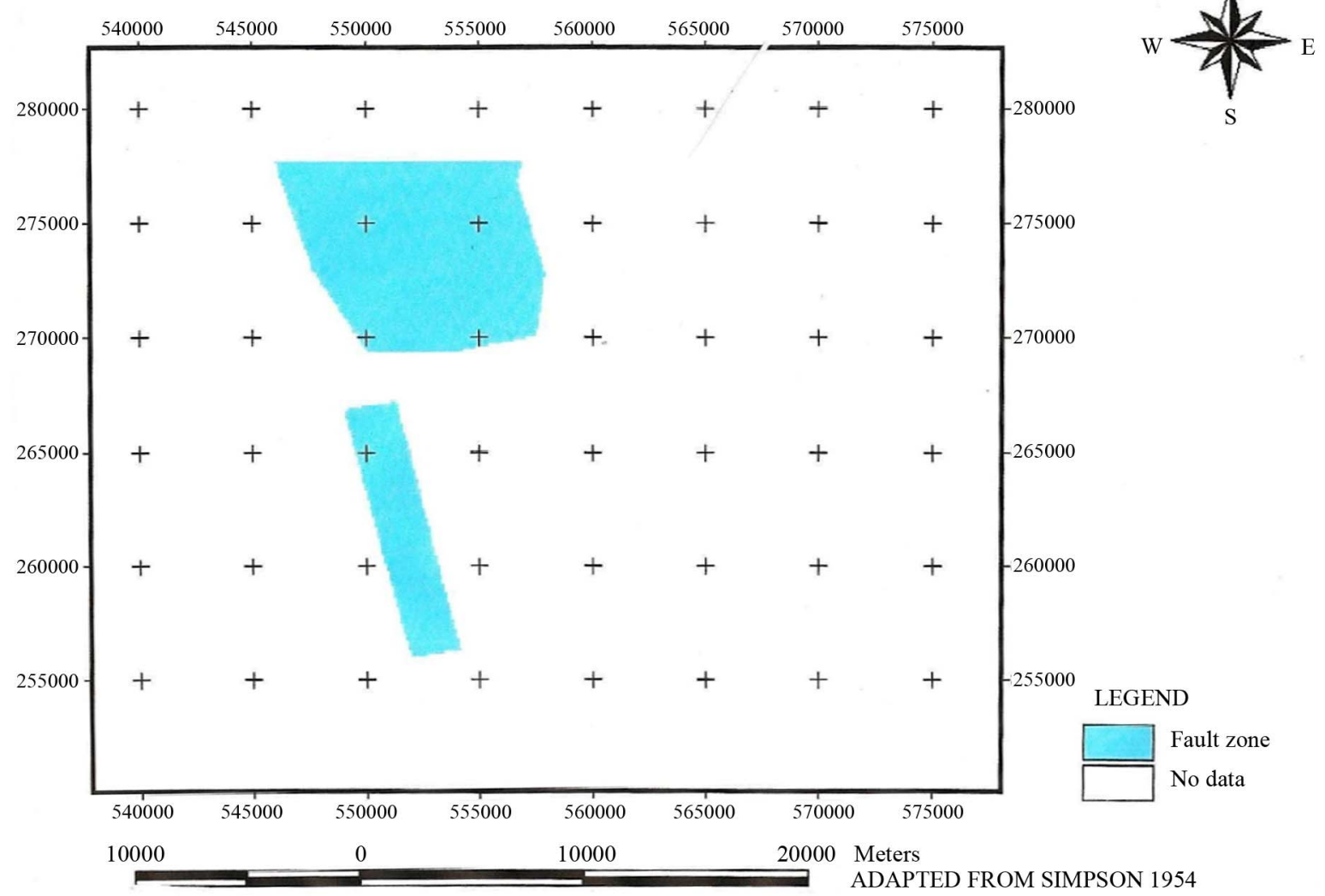

Figure 19. Digitized and buffered fault map. 


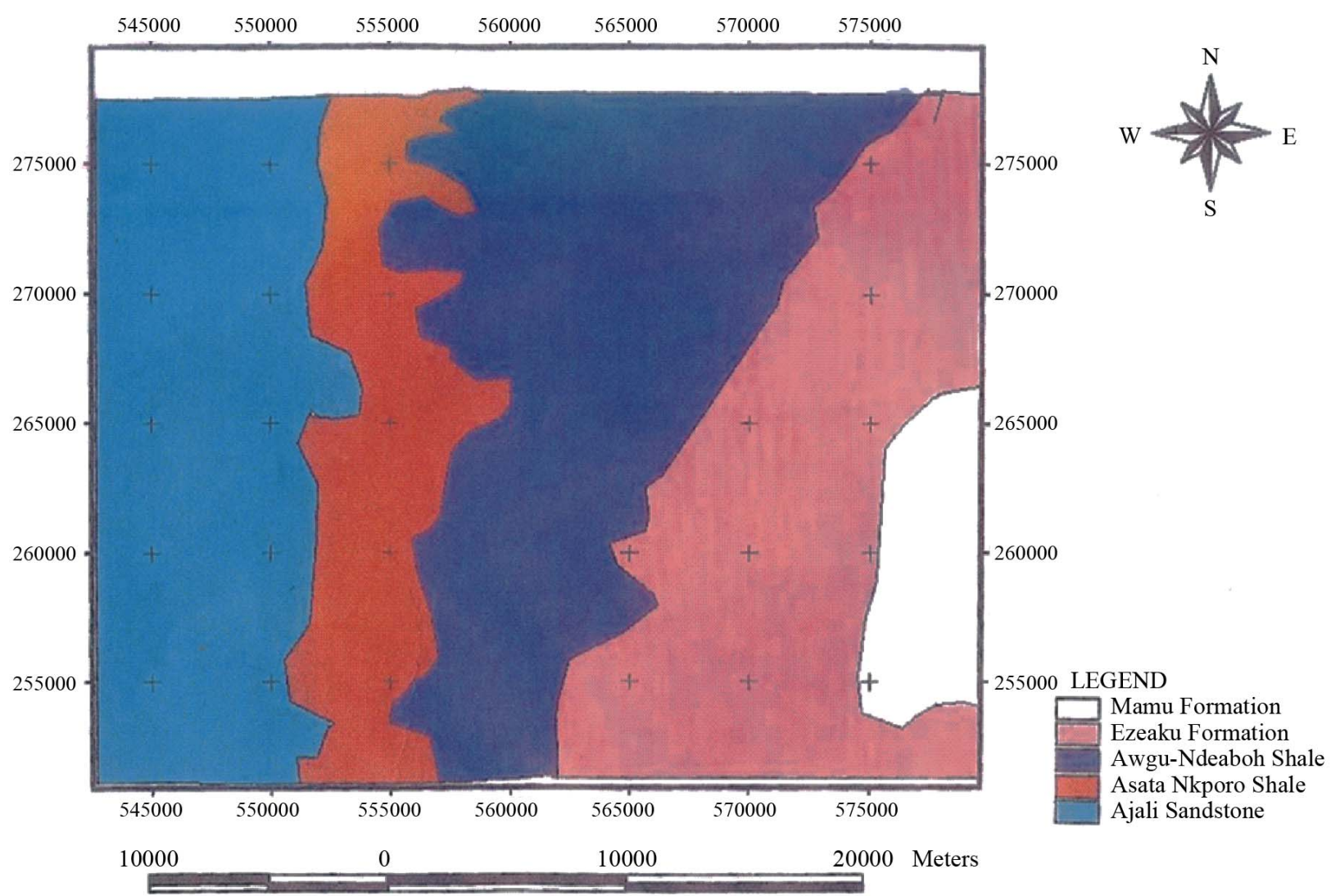

Figure 20. Digitized geological map of Enugu area and environs.

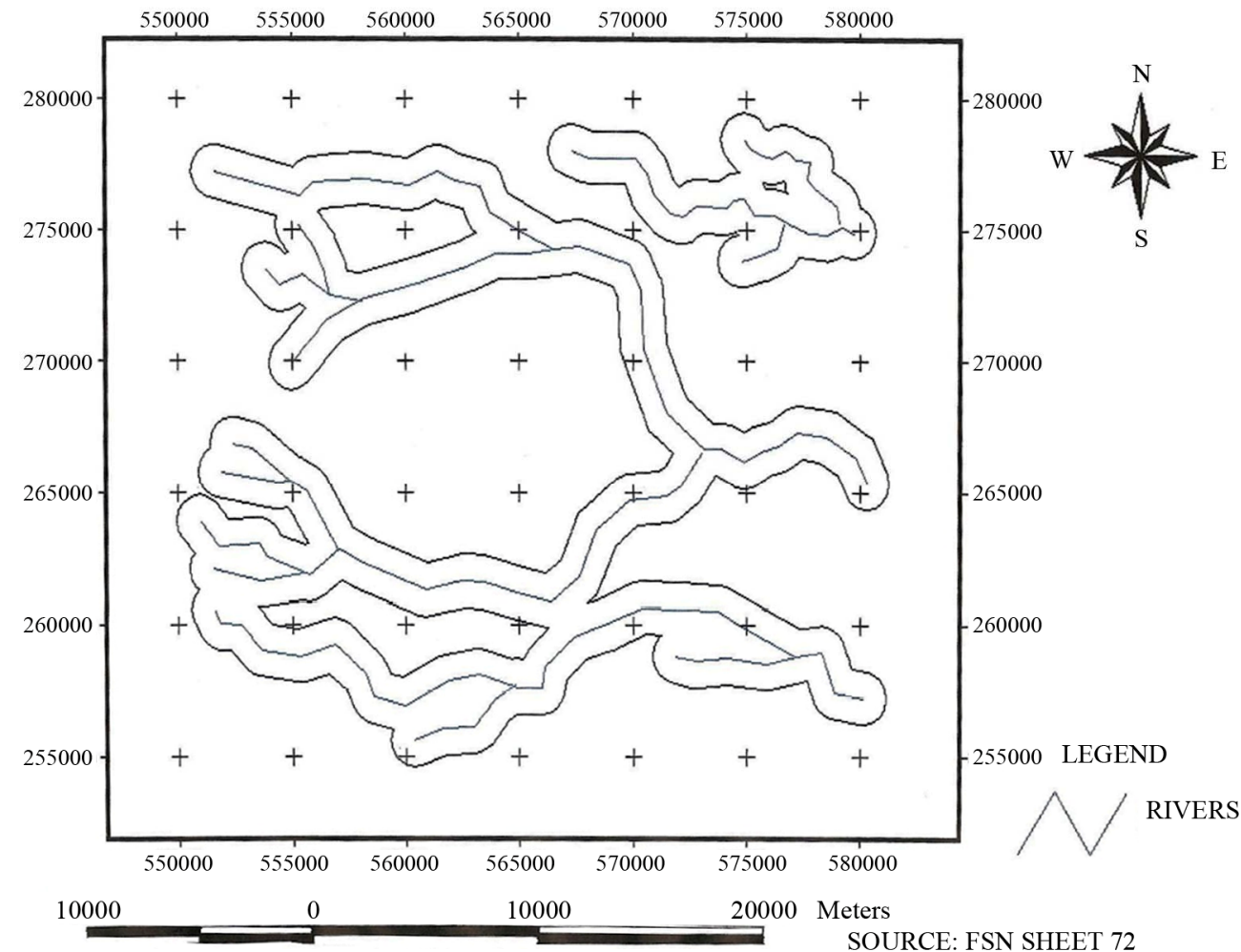

Figure 21. Digitized, buffered, landslide and flooded area. 


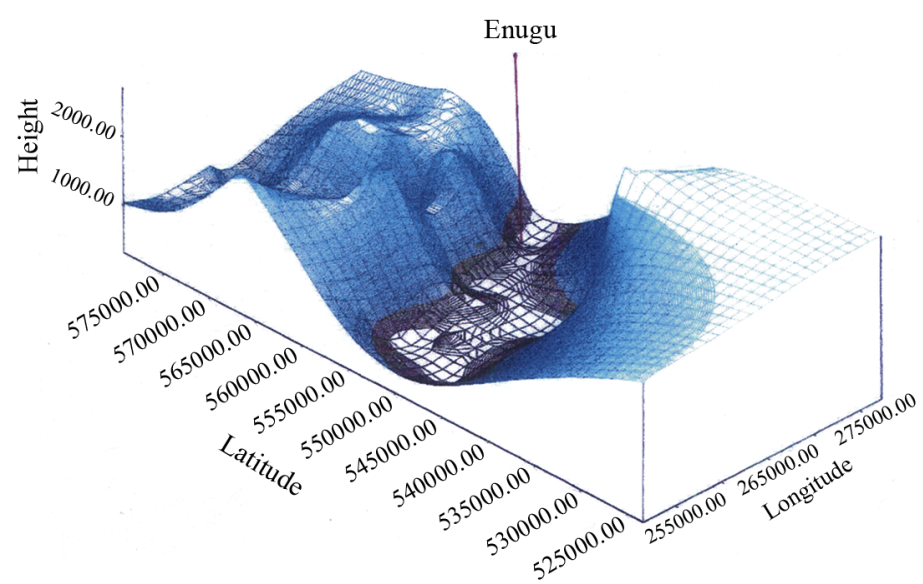

Figure 22. Digital terrain model map of Enugu area.

Table 10. Organization of thematic data layers for waste disposal landuse option.

\begin{tabular}{|c|c|c|c|c|c|}
\hline Input Theme & $\begin{array}{l}\text { Percentage } \\
\text { Influence }\end{array}$ & $\begin{array}{l}\text { Input } \\
\text { Field }\end{array}$ & Input Label & Scale Value & Remarks \\
\hline $\begin{array}{l}\text { Slope Theme } 1 \\
\text { (Layer 1) }\end{array}$ & $10 \%$ & $\begin{array}{l}1 \\
2 \\
3\end{array}$ & $\begin{array}{l}\text { 0-9(Gentle Slope) } \\
9-19 \text { ( sloppy) } \\
>19 \text { ( steep) }\end{array}$ & $\begin{array}{l}2 \\
1 \\
0\end{array}$ & $\begin{array}{l}\text { Down migration of } \\
\text { leachate }\end{array}$ \\
\hline $\begin{array}{l}\text { Elevation Theme } 2 \\
\text { (Layer 2) }\end{array}$ & $6 \%$ & & & & $\begin{array}{l}\text { Used in the derivation of } \\
\text { DEM for slope } \\
\text { computation }\end{array}$ \\
\hline $\begin{array}{l}\text { Soil Depth Theme } 3 \\
\text { (Layer 3) }\end{array}$ & $5 \%$ & $\begin{array}{l}1 \\
2 \\
3\end{array}$ & $\begin{array}{l}\text { Deep } \\
\text { Deep } \\
\text { Shallow }\end{array}$ & $\begin{array}{l}2 \\
2 \\
1\end{array}$ & Attenuation of pollutants \\
\hline $\begin{array}{l}\text { Geology Theme } 4 \\
\text { (Layer } 4 \text { ) }\end{array}$ & $20 \%$ & $\begin{array}{l}1 \\
2 \\
3 \\
4 \\
5\end{array}$ & $\begin{array}{l}\text { Ajali FM } \\
\text { Mamu FM } \\
\text { Asata/Nkporo } \\
\text { Awgu-Ndi Abo } \\
\text { Ezeaku }\end{array}$ & $\begin{array}{l}2 \\
1 \\
1 \\
2 \\
1\end{array}$ & $\begin{array}{l}\text { Based on geological } \\
\text { characteristics e.g. } \\
\text { Fractured rocks enhance } \\
\text { the migration of pollutants }\end{array}$ \\
\hline $\begin{array}{l}\text { Drainage Theme } 5 \\
\text { (Layer 5) }\end{array}$ & $10 \%$ & $\begin{array}{l}1 \\
2 \\
3\end{array}$ & $\begin{array}{l}\text { Moderate } \\
\text { Moderate } \\
\text { Well Drained }\end{array}$ & $\begin{array}{l}1 \\
1 \\
2\end{array}$ & $\begin{array}{l}\text { Poorly Drained soil can } \\
\text { lead to reducing } \\
\text { conditions }\end{array}$ \\
\hline $\begin{array}{l}\text { Soil Class Theme } 6 \\
\text { (Layer 6) }\end{array}$ & $5 \%$ & $\begin{array}{l}1 \\
2 \\
3 \\
4\end{array}$ & $\begin{array}{l}\text { Sandy (Foralithic) } \\
\text { Clayey Sand (Hyromorphic) } \\
\text { Silty Sand (Lithosoil) } \\
\text { Sandy Clay (Ferralithic) }\end{array}$ & $\begin{array}{l}1 \\
2 \\
0 \\
1\end{array}$ & $\begin{array}{l}\text { Based on soil } \\
\text { Engineering classification }\end{array}$ \\
\hline $\begin{array}{l}\text { Surface Water } \\
\text { Theme } 7 \text { (Layer 7) }\end{array}$ & $8 \%$ & Buffered & & & $\geq 1000 \mathrm{~m}(1 \mathrm{~km})$ \\
\hline $\begin{array}{l}\text { Depth To Water Table } \\
\text { Theme } 8 \text { (Layer } 8 \text { ) }\end{array}$ & $9 \%$ & $\begin{array}{l}1 \\
2 \\
3\end{array}$ & $\begin{array}{l}\text { Very Shallow } \\
\text { Shallow } \\
\text { Deep }\end{array}$ & $\begin{array}{l}1 \\
2 \\
3\end{array}$ & $\begin{array}{l}\text { Can be polluted when } \\
\text { shallow }\end{array}$ \\
\hline $\begin{array}{l}\text { Erosion Theme } 9 \\
\text { (Layer 9) }\end{array}$ & $8 \%$ & $\begin{array}{l}1 \\
2\end{array}$ & $\begin{array}{l}\text { Buffered } \\
\text { Active } \\
\text { Non Active }\end{array}$ & $\begin{array}{l}0 \\
0 \\
0\end{array}$ & $\begin{array}{l}\text { Can distribute wastes GIS } \\
\text { Buffer } \geq(1 \mathrm{~km})\end{array}$ \\
\hline $\begin{array}{l}\text { Escarpment Theme } 10 \\
\text { (Layer 10) }\end{array}$ & $4 \%$ & & $\begin{array}{l}\text { Scarp } \\
\text { Crest } \\
\text { Dip }\end{array}$ & $\begin{array}{l}0 \\
1 \\
2\end{array}$ & $\begin{array}{l}\text { Escarpment is } \\
\text { characterized by high } \\
\text { slope. }\end{array}$ \\
\hline $\begin{array}{l}\text { Flooded/Land Slide } \\
\text { Theme } 11 \text { (Layer 11) }\end{array}$ & $5 \%$ & $\begin{array}{l}1 \\
2\end{array}$ & $\begin{array}{l}\text { Buffered } \\
\text { Active } \\
\text { Non Active }\end{array}$ & $\begin{array}{l}0 \\
0\end{array}$ & $\begin{array}{l}\text { Reducing condition } \\
\text { distribution of wastes and } \\
\text { leachate Buffer } \geq 1 \mathrm{~km} \text { ) }\end{array}$ \\
\hline $\begin{array}{l}\text { Fault Theme } 12 \\
\text { (Layer } 12 \text { ) }\end{array}$ & $10 \%$ & $\begin{array}{l}1 \\
2\end{array}$ & $\begin{array}{l}\text { Buffered } \\
\text { Active } \\
\text { Non Active }\end{array}$ & $\begin{array}{l}0 \\
0 \\
0\end{array}$ & $\begin{array}{l}\text { Can create pathway for } \\
\text { leachate migration to } \\
\text { ground water. GIS buffer } \\
\geq(1 \mathrm{~km})\end{array}$ \\
\hline Total & $100 \%$ & & & & \\
\hline
\end{tabular}




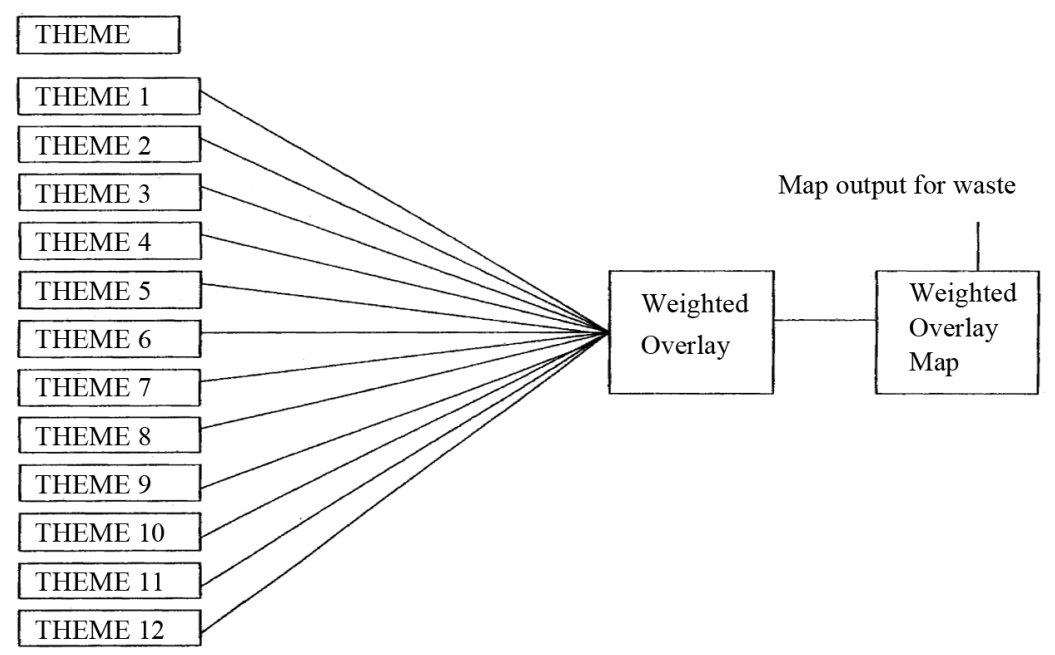

Figure 23. Overlay model for waste disposal land use.

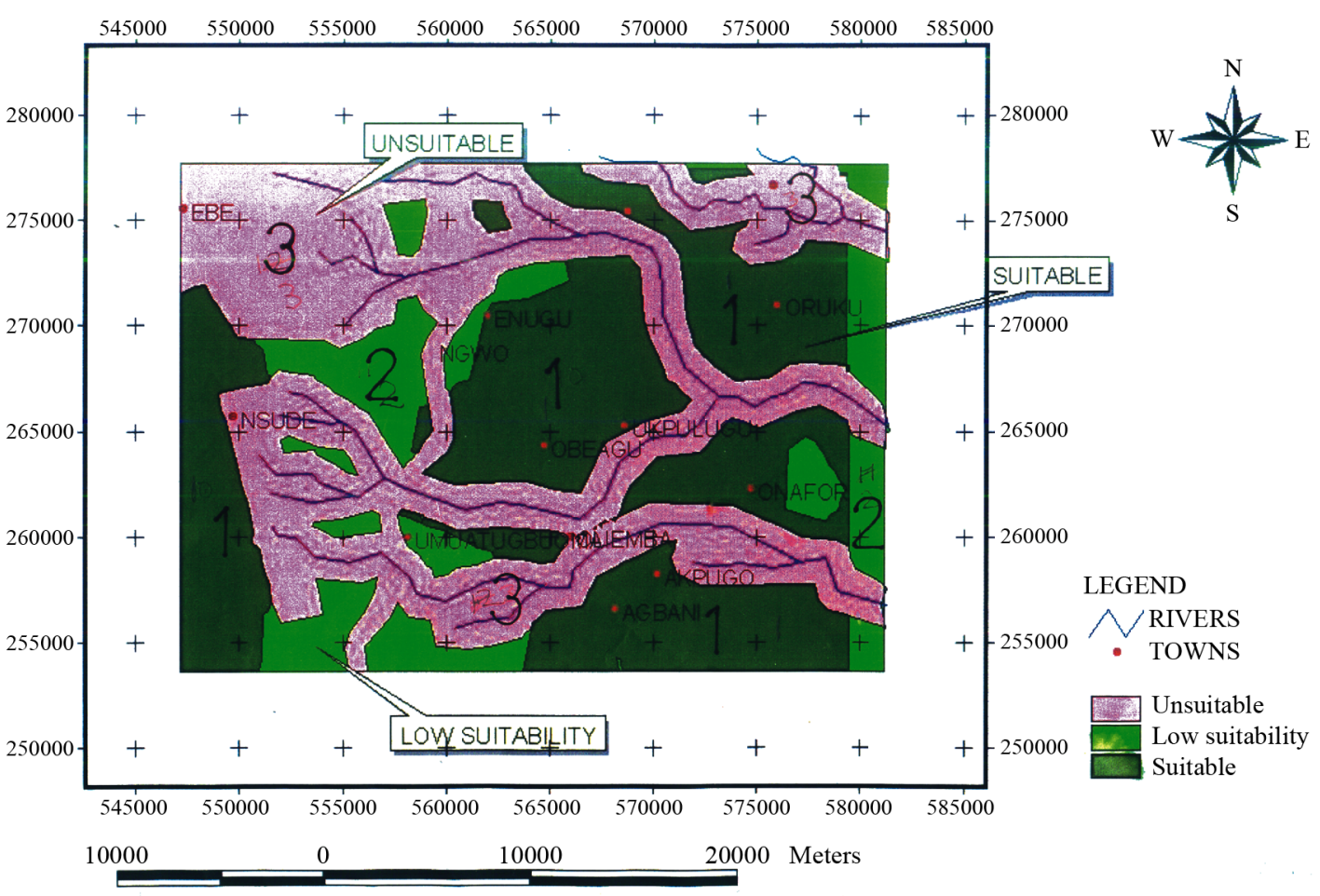

Figure 24. Suitability map for waste disposal land use option in Enugu area.

waste disposal except Enugu Metropolis. The western quadrant is suitable due to low water table conditions, considerable soil thickness of about $19 \mathrm{~m}$ and very high sorption capacities due to the presence of fines in the samples. Areas of low suitability for waste disposal (Area 2: Ngwo area) occupy 20\% of the land area, and falls mainly around the escarpment and the eastern end of the map. The low suitability in Area 2 is a function of steep slopes of around $50 \%$, seepage at the foot of the escarpment due probably to high pore water pressure, and very shallow water table conditions. The unsuitable zones for waste disposal-Area 3 (Ebe/Nsude areas) also occupy about $20 \%$ of the land area and correspond to fault zones, scarp face terrain, flood and landslide prone areas.

If a terrain is suitable for waste disposal, such a land has an advantage over unsuitable areas as leachates are easily attenuated by natural processes, hence the environment is protected and safe for man to live. Natural protection also saves huge costs required in waste management, especially in constructing engineered systems in areas that have high suitability for residential land use 
but low suitability for waste disposal landuse option. In such areas the international standard practice of leachate treatment, containment and discharge into the environment should be observed.

The area at Ugwuaji off Enugu-Port Harcourt expressway presently mapped out and used by Enugu State Environmental Sanitation Authority (ESESA) for the disposal of the wastes falls in one of the areas of high suitability of the present study. This implies that its present position is well cited. Most industries and residential buildings within Enugu Metropolis also correspond to areas of low suitability for waste disposal.

\section{Conclusion}

This study has shown that the area suitable for waste disposal practices in Enugu Area cover the greater percentage of the land unit and are found within the western, central and to a reasonable extent, the eastern blocks. Some of the available lands were adjudged unsuitable due to faults, erosion, landslides, floods and scarp face. This study is therefore expected to form the basis for future landuse management for enhanced sustainable development and better planning of Enugu area and environs.

\section{REFERENCES}

[1] L. V. Dutra and R Hober, "Primary Forest and Landcover Contextual Brazil Proceedings on International Geosciences and Remote Sensing Symposium," USA, 1998, pp. 5-35.

[2] "Nigerian Population Census," Enugu State Government Gazette, 2006.

[3] C. C. Raymond, "Land Application of Wastes," John Wiley and Sons Publishers, Hoboken, 1979, pp. 150-160.

[4] S. A. Griffiths, "Land Treatment of Leachate for Municipal Landfills Nayea Publications," 1981, pp. 210-216.

[5] P. N. Gauley and R. B. Korne, "Soil Mantle as a Waste Treatment System," University of California, Berkely, 1966, pp. 120-131.

[6] W. R. Aria, "Principles of Geotechnics, Environmental Protection Service," Harwood Academic Publishers, New York, 2003, pp. 85-124

[7] R. Davis and G. Rogers, "Landfill Evaluation and Siting Study New Jersey," John Wiley and Sons Publishers, Hoboken, 1975, pp. 240-285.

[8] P. Crynine, "Land Disposal of Solid Wastes CBS Publishers and Distributors," New Deihi, 1977, pp. 850-930.

[9] C. B. Hunt, "Geology of Soils, Their Evolution, Classification and Uses," W. H. Freeman, San Francisco, 2002, pp. 130-172.

[10] M. J. Hammer, "Water and Waste Water Technology," 2nd Edition, Wiley publisher's, New York, 2003, pp
230-238.

[11] P. C. Sidle, "Relative Importance of Factors Influencing Landsliding in Coastal Alaska," Proceedings of Annual Engineering Geology and Soil Engineering Symposium, Juneau, 1985, pp. 34-38.

[12] D. A. Holland and S. L. Smith, "The Effect of Changing Grid in the Creation of Laser Scanner, Digital Surface Models in Geo-Computation," Oxford University Press, Oxford, 2003, pp. 230-240.

[13] V. C. Kang, "Introduction to Geographic Information System," Tata McGraw-Hill Publishing Company Ltd., New Delhi, 2002, pp. 20-25.

[14] N. P. Iloeje, "A New Geography of Nigeria," Revised Edition, Williams Clowes Ltd., London, 1981, pp. 85120.

[15] R. A. Reyment, "Aspect of the Geology of Nigeria," Ibadan University Press, Ibadan, 1965, pp. 22-38.

[16] G. E. K Ofomata, Technical Report on Feasibility Study of Erosion Vulnerability Areas in the Eastern Part of Nigeria Ethiope Publishing House, Britain, 1985, pp. 35-37.

[17] L. C. Amajor, "Sedimentary Facies Analysis of the Campano-Maestritchtian Ajali Sandstone Okigwe Area Nigeria," 20th Annual Conference of Nigeria Mining and Geosciences Society, Vol. 13, Nsuka, 1984, p. 11.

[18] B. C. E. Egboka, "Water Resources Problem in the Enugu Area of Enugu State," Nigerian Journal of Mining Geology, Vol. 20, 1993, pp. 1-6.

[19] R. C. Murat, "Stratigraphy and Paleogeography of Cretaceous and Lower Tertiany in Southern-Nigeria, African Geology," Ibadan University Press, Ibadan, 1972, pp. 251-266.

[20] A. Simpson, "The Nigerian Coal Field: The Geology of Part of Onitsha, Owerri and Benue Provinces," Geology Survey Nigeria Bulletin, 1954, p. 24.

[21] G. I. Nwankwo, B. C. Egboka and I. P. Orajaka, "Groundwater Occurrence and Flow Patterns in the Enugu Coal-Mine Areas, Anambra State, Nigeria," $\mathrm{Hy}$ drological Sciences Journal, Vol. 33, No. 5, 1988, pp. 465-485. doi: 10.1080/02626668809491275

[22] E. C. Ezeanyim, "Hydrogeology of Enugu Area and Environs," Master's Thesis, University of Nigeria, Nsukka, 1988.

[23] B. C. E. Egboka and F. O. Onyebueke, "NAH Journal on Acute Hydro-Geological Problems, VIS a VIS Planning and Management of Developing Economy. A Case Study of Enugu Area, Nigeria," 1999.

[24] “Annual Book of ASTM Standard Vol. 04, Soil and Rock Standard Practice for Particle Size Analysis and Determination of Soil Constants," West Conshokockem, 2000, pp. 8-9.

[25] Chengliu and Evett, "Soil Properties," 2nd Edition, Prentice Hall Inc., Englewood Cliffs, 2000, p. 28.

[26] F. J. Chapin, "Urban Land Use Planning," University of Illinois Press, Champaign, 1965, pp. 34-48. 